\title{
Novedades sobre la arx Hasdrubalis de Qart Hadast (Cartagena): nuevas evidencias arqueológicas de la muralla púnica ${ }^{1}$
}

\author{
José Miguel NOGUERA CELDRÁN \\ (Universidad de Murcia) \\ María José MADRID BALANZA \\ Víctor VELASCO ESTRADA \\ (Excavación Arqueológica del Molinete)
}

\begin{abstract}
Resumen
Las excavaciones arqueológicas acometidas entre 2010 y 2011 en la cima del cerro del Molinete (Cartagena, España), han permitido constatar una estructura arquitectónica longitudinal formada por dos paramentos paralelos con compartimentos internos construidos con muros rectangulares a modo de tirantes. Tipológicamente, parece corresponder a una muralla de casamatas. Los materiales cerámicos procedentes de los estratos de destrucción y amortización de la estructura se fechan a finales del siglo III o inicios del II a.C., de donde la posibilidad de interpretarla como un tramo de la muralla construida por los fundadores de la ciudad púnica, destinada a defender la ciudad y su acrópolis (arx Hasdrubalis) por su flanco norte.
\end{abstract}

Palabras clave: Qart Hadast, Cartago Nova, ciudad púnica de Cartagena, muralla casamatas.

\section{Summary}

The archaeological excavations undertaken during the years 2010 and 2011 in the top of

"Cerro del Molinete", Cartagena, Spain, have allowed us to state the existence, architecturally speaking, of a longitudinal structure, which consisted of two parallel faces with several inner compartments or sections that were built using rectangular walls as braces. Tipologically, this structure seems to belong to a casamates wall. The ceramic materials, coming from the refered stratified structure's rubbles, date from the end of the III century B.C. or the begining of the II century B.C.; that is why we think about the possibility this structure may be interpreted as a stretch of the wall that was built by the carthaginian town's founders and whose aim could be to defend the town and its acropolis (arx Hasdrubalis) by the northern side.

Keywords: Qart Hadast, Cartago Nova, punic city of Cartagena, casamates wall.

Qart Hadast, la Nueva Cartago, fue fundada hacia 229/228 a.C. (tras la muerte de Hamílcar a manos de Orissón, monarca de los oretanos [App. $I b .5])$ por su yerno y sucesor Hasdrúbal, después de firmar alianzas personales con los reguli ibéri-

1 Este trabajo se enmarca en el proyecto de investigación titulado "Roma y las capitales provinciales de Hispania. La gran arquitectura pública de Cartago Nova" (ref. nº HAR2009- cos y contraer matrimonio con la hija de uno de ellos. La "fundación" -como así la denominó Diodoro Sículo (XXV, 11-12)- aconteció en un punto geoestratégico del sureste peninsular, no en exceso alejado de la propia Cartago, al objeto se 
servir, en el marco de sus planes imperialistas, de capital militar y económico-comercial del protectorado ibérico de los Barca (Pol. II, 13, 1; Diod. $\mathrm{XXV}, 10,12)$.

La plaza púnica, concebida en todo caso por sus proyectistas como una ciudad (Conde, 2003:41), se asentó en una pequeña península (de unas 40 ha de extensión) que, ocupada por sendas vaguadas -con orientación noreste-suroeste y sureste-noroeste-, estaba emplazada al fondo de una profunda bahía y rodeada por el mar por el sur, sureste y suroeste (Mar de Mandarache), así como por una amplia laguna interior (Almarjal) al norte. La península, unida al noreste a tierra firme por un istmo por el que penetraba, en origen, la uia Heraclea, posterior vía Augusta, estaba bordeada por un cinturón de cinco cerros de diferente altura y magnitud ${ }^{2}$, en las cimas y laderas de algunos de los cuales puede rastrearse arqueológicamente la existencia de una población ibérica precedente de difícil caracterización, al menos, desde finales del siglo $\mathrm{V}$ a.C. o inicios del siguiente (Noguera, 2003:20-21; Ramallo - Ruiz, 2009:527-532). En este sentido, el término "fundar" empleado por Diodoro debió implicar la modificación de la fisonomía del poblado preexistente y la construcción de nuevos edificios (Conde, 2003:39). De hecho, Polibio (II, 13, 1) alude no tanto a la fundación como a la "organización" de la nueva ciudad, materializada en la transformación del anterior asentamiento ibérico (Conde, 2003:41). La población de la ciudad, muy helenizada, estuvo integrada básicamente por artesanos, obreros o marineros encargados de las actividades comerciales y edilicias (Pol. X, 8, 5; Bendala - Fernández Ochoa - Fuentes - Abad, 1987:121-140).

El emplazamiento escogido para la nueva ciudad era un puerto natural inmejorable y una plaza fuerte casi invulnerable. Como base naval y lugar de invernaje del ejército, fue el principal centro de operaciones militares de las tropas cartaginesas acantonadas en la península Ibérica. La elección del nuevo enclave cartaginés sin duda valoró, además de su posición estratégica, la posibilidad de aprovechamiento de los recursos agropecuarios del rico territorio circundante $\mathrm{y}$, sobre

2 Una óptima descripción de la topografía de la península en Pol. X, 10; los reajustes de orientación al texto polibiano y la mejor restitución de la orografía de la ciudad puede verse todo, su situación en las inmediaciones de una sierra riquísima en plomo y galenas argentíferas, beneficiadas ya desde antiguo por la población nativa ibérica, cuya explotación permitió obtener plata con que hacer frente a los costes de la guerra contra Roma. De hecho, la intensidad del usufructo de las minas pronto derivó en acuñación de moneda de plata de elevada ley con que sufragar los cuantiosos gastos del Estado cartaginés y los derivados del pago de salarios a los mercenarios (Lechuga, 1991-93:155-165). Este cuadro estratégico y económico impulsó el dinamismo de su puerto, cuya intensa actividad estuvo al servicio de los intereses económicos de Cartago en el levante y mediodía peninsulares, sin duda anteriores al periodo fundacional, aunque dotados ahora de un excepcional puerto redistribuidor vinculado directamente a la metrópoli norteafricana (Pérez, 1998:249-261). Ello dotó a esta última -privada en estas fechas de sus mercados en el Mediterráneo central- de un inmejorable puerto proveedor de avituallamientos y receptor de sus producciones (Pol. X, 8, 2-3). Los dragados y trabajos de prospección arqueológica efectuados en el área de la bahía han permitido constatar gran cantidad de material anfórico del último tercio del siglo III a.C., en correspondencia con este periodo de dominio bárquida (Guerrero Roldán, 1992). Por otro lado, los contextos de importación documentados en el transcurso de las campañas arqueológicas dirigidas, entre 1977 y 1978, en el cerro del Molinete por P. San Martín y bien estudiados por E. Ruiz, destacan por el elevado porcentaje de producciones del área septentrional campana, de Cales y de Ischia, datables a fines del siglo III e inicios del II a.C. (Ruiz, 1999:35-38); estos productos debieron arribar gracias a la intermediación de los comerciantes cartagineses. Además, es probable que, tras su fundación, la ciudad regularizara los flujos comerciales entre Iberia y el norte de África, convirtiéndose en el eslabón peninsular para la redistribución de mercancías bajo la órbita de Cartago, lo que permitiría el abastecimiento de la ciudad y la apertura de nuevos mercados en su área de influencia (Martín - Roldán, 1991-92:en particular 158 y 160). 
Aunque conocemos pocos datos referentes a la urbanística de la ciudad a finales del siglo III a.C., en las dos décadas en que estuvo bajo control bárquida debió experimentar la primera ordenación de su solar urbano, de la que sin duda fue tributario el posterior desarrollo de la ciudad romana de época republicana e imperial (Bendala, 1990:25-29; Ramallo - Ruiz, 2009:525-541). En aquella época debieron diseñarse los primeros espacios públicos y religiosos -un ágora (Pol. X, 16, 1) y los santuarios de Cronos y Hefesto en el Monte Sacro y el cerro de Despeñaperros (Pol. X, 10, 10)- de los que no tenemos información arqueológica alguna (Martín Camino, 1994:319). Por el contrario, sabemos que se aterrazaron y urbanizaron las laderas de los cerros, quedando reservados buena parte de estos declives para el hábitat doméstico (Martín Camino - Roldán Bernal, 1992; Madrid Balanza, 2004:31-40). También se diseñaron los principales ejes viarios (Martín Roldán, 1997:128), algunos de cuyos trazados pervivirán a grandes rasgos en épocas romana e, incluso, moderna.

En el contexto de inestabilidad de las décadas finales del siglo III a.C. y respondiendo a planteamientos tácticos y poliorcéticos, la principal de las actuaciones acometidas por los cartagineses fue, sin duda, la construcción de unas sólidas defensas, diseñadas -por cuanto conocíamos hasta ahora gracias al tramo de muralla hallado en el solar del antiguo colegio de La Milagrosasegún tipologías propias de la arquitectura militar de raigambre fenicio-púnica e imbuidas de tradiciones helenísticas en lo que a técnicas y concepción arquitectónica se refiere.

El perímetro amurallado de la ciudad púnica fue mayor que el de la posterior romana -que medía 20 estadios (Pol. X, 10, 1; Ruiz - Madrid, 2002:25), es decir, unos 3500/3700 m en función del tipo de medida utilizada-, aunque su espacio interior no fue ocupado en su integridad. A pesar de sus sólidas defensas, la capital fue sitiada y conquistada por el general P. Cornelius Scipio, asistido por los legados C. Laelius y L. Marcius,

3 Schulten, 1935:118; De Sanctus, 1968:440, nt. 18; Walbank, 1976, vol. 2:14-15. Otros autores toman como válida la fecha de 210 a.C. aportada por T. Livio (Lancel, 1997:183). Sobre la posibilidad de un asedio anterior: Liv XXII, 20; y también en el invierno de los años 209-208 a.C. (Pol. X, 6, 8; X, 8-15; sobre este episodio: Fernández Rodríguez, 2005:31-72; con anterioridad; Beltrán, 1946:101-111; id., 1947:134-143)³. Si creemos a Polibio, las destrucciones causadas por el ataque fueron limitadas (Pol. X, 12-15), siendo la ciudad reocupada y no arrasada en su totalidad, aunque son diversos los puntos donde el registro arqueológico acredita niveles de incendio y ruina asociados al acontecimiento bélico. Con ello, el proyecto cartaginés quedó abortado y comenzó, ahora bajo dominio de la República de Roma, la andadura de una de las más prósperas, ricas y cosmopolitas metrópolis de la Hispania romana, cuya historia -no obstante- fue tributaria y estuvo inevitablemente ligada a la de la fundación cartaginesa, como bien apreció M. Bendala (1990:25-29) también al respecto de otros establecimientos púnicos del mediodía peninsular.

La colina que delimitaba por el noroeste la península, separándola del estero o laguna interior, jugó un papel fundamental en el contexto de la réplica ibérica de Cartago. Se trata del actual cerro del Molinete -uno de los accidentes orográficos que más y mejor ha caracterizado la topografía y fisonomía urbana de la ciudad de Cartagena en el devenir de los siglos-, del que Polibio $(X, 10,9)$ refirió a mediados del siglo II a.C. que en él fue construido por Hasdrúbal, cuando afectaba la monarquía, un suntuoso palacio, de ahí su consideración de ciudadela (arx Hasdrubalis). Y aunque la aseveración polibiana no había encontrado hasta el momento correspondencia en el registro arqueológico del promontorio $^{4}$, su historia ha estado indisociablemente ligada al nombre del caudillo cartaginés, generando un mito popular (definido por una mezcolanza de historia, arqueología, leyendas y tradiciones) que ha calado hondo en el imaginario colectivo de una ciudad que siempre se ha sentido tributaria y orgullosa de su origen púnico-norteafricano.

Sin embargo, el registro arqueológico documentado en el transcurso de las excavaciones
De Miquel, 1994:55-59; en contra: Fernández, 2005:55-56.

4 Sobre la documentación arqueológica procedente del cerro del Molinete y sus áreas adyacentes: Noguera (Ed.), 2003; Noguera - Madrid (Edd.), 2009. 


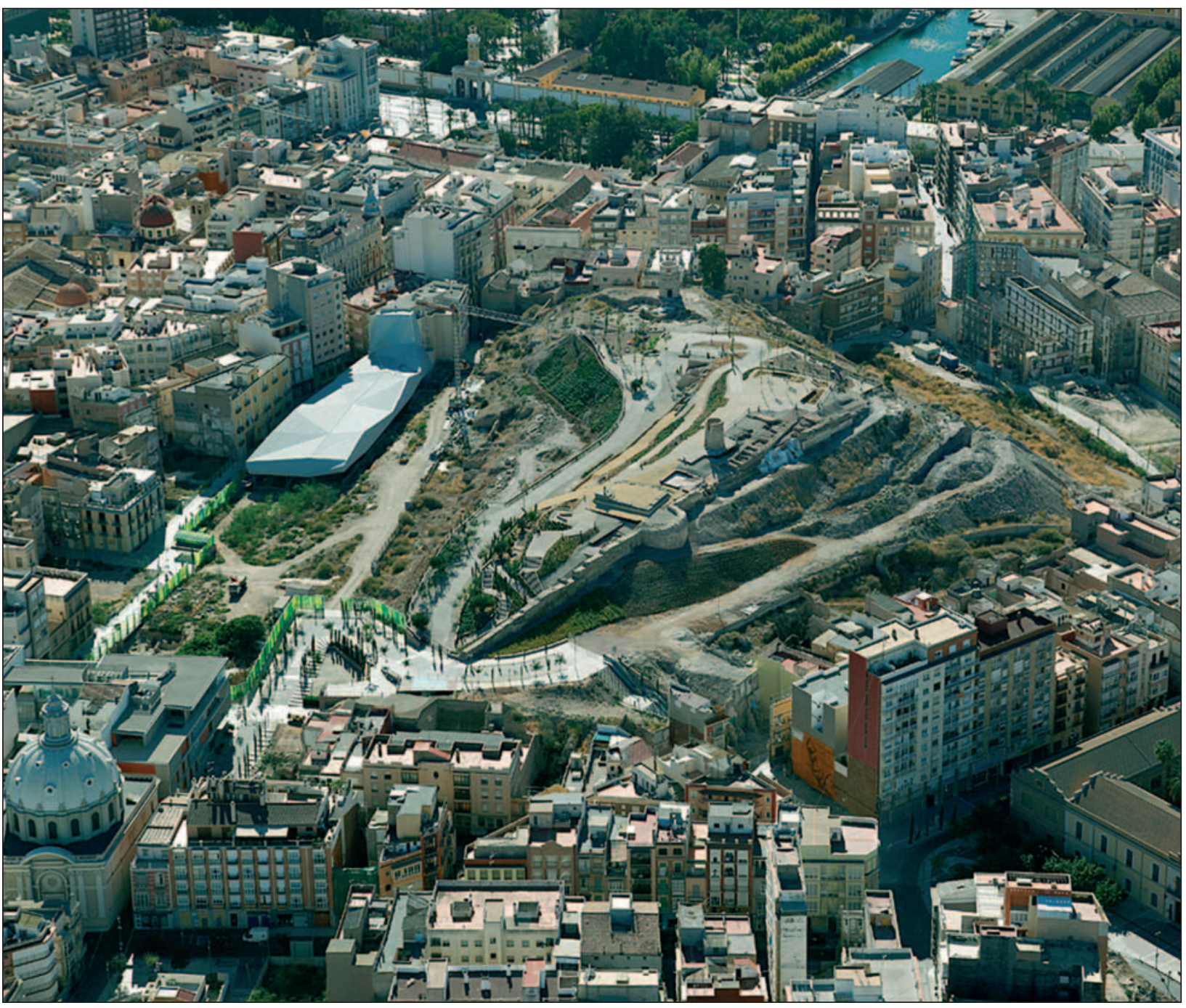

Figura 1. Vista aérea del Parque Arqueológico del Molinete desde el noreste (fot. Paisajes Españoles)

acometidas entre 2010 y 2011 con ocasión de las obras de ejecución en la cima del cerro de un parque-jardín arqueológico (figs. 1-2), permite constatar una interesante secuencia material relativa a su ocupación en épocas cartaginesa y romano-republicana. Y aunque estamos concluyendo el estudio de dicha documentación, nos ha parecido pertinente avanzar en el Homenaje que la Universidad Autónoma de Madrid tributa al profesor Manuel Bendala Galán, los resultados del estudio preliminar de las estructuras y contextos púnicos hallados en la cima del cerro, los cuales -con la debida cautela y discreciónpodrían vincularse con la construcción del sistema defensivo de la ciudad, en concreto en la parte más elevada de la vertiente nororiental del cerro bañada otrora por las aguas del Almarjal. Precisamente con el Dr. Bendala tuvimos la oportunidad -con ocasión de su asistencia a la
Reunión científica "Espacios y función en las áreas públicas romanas: los elementos singulares", celebrada en Cartagena los días 20 y 21 de octubre pasado-, de pasear por el Molinete y mostrarle estos y otros hallazgos que configuran un escenario arqueológico que, por ser uno de sus más sentidos temas de estudio, le cautivó sobremanera, llegándole incluso a emocionar. Rememorando las palabras del propio Bendala con ocasión de este periplo por el cerro, estos trabajos y, en su conjunto, el Parque Arqueológico del Molinete, ponen el acento sobre la realidad material desde la que se creó y cimentó el dominio ibérico de los Barca. Con ellos, nuevamente, Cartagena se convierte en capital de proyección universal gracias a su patrimonio cultural y a su Historia milenaria. Sirvan, así pues, las páginas que ahora siguen de sentido regalo y homenaje al buen colega y amigo. 


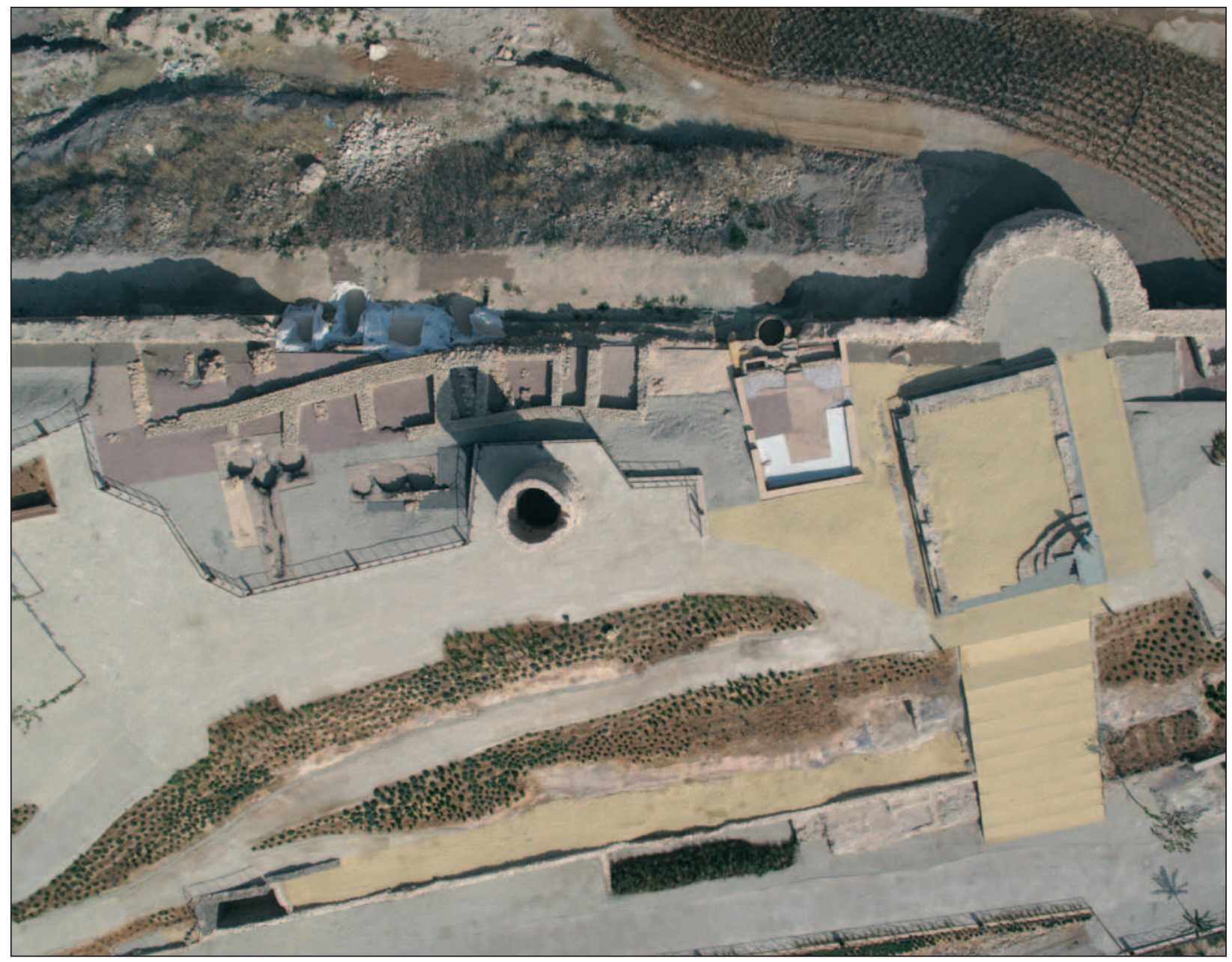

Figura 2. Parque arqueológico del Molinete. Vista aérea del área occidental del denominado sector A con los restos arqueológicos puestos en valor de la muralla púnica (cubiertos con geotextil),

la muralla romana superpuesta y el santuario púnico-romano de Atargatis (fot. J. G. Gómez Carrasco).

\section{LAS ESTRUCTURAS DE LA CIMA DEL CERRO DEL MOLINETE: LA EVIDENCIA ARQUEOLÓ- GICA DE ÉPOCA PÚNICA}

Las excavaciones arqueológicas de 2010-2011 en la cima del Molinete se han centrado en dos áreas bien definidas ${ }^{5}$. Por un lado, en el antiguo sector A definido por San Martín en los años 70 del siglo pasado -integrado por los vestigios de un santuario púnico-romano dedicado a Atargatis, un templo itálico de época republicana y algunas estructuras definidas como "viviendas indígenas" (Roldán, 2003:86-89, fig. 2), donde se ha pretendido completar la documentación arqueológica existente y acometer la puesta en valor del área excavada. Por otro, en la zona de la denominada
Muralla del Deán - proyectada en el siglo XVI por el propio Carlos I y construida por Sebastián Clavijo, deán de la Catedral de Cartagena, en Murcia (Gómez, 2003:279-284, láms. 1-2)- que delimitaba por el norte la mitad occidental del sector A y que se desplomó en febrero de 2010 tras un período de fuertes lluvias, justo en los meses previos al inicio de nuestros trabajos (fig. 3); esta circunstancia posibilitó ampliar el área de trabajo prevista inicialmente, proyectándose la excavación de un perfil de tierra con orientación oesteeste, hasta entonces ocupado por la cimentación de la muralla moderna. La actuación arqueológica en esta zona, que ha permitido documentar estructuras y estratigrafías antiguas selladas desde el siglo

5 Un avance preliminar en: Giménez - Noguera - Madrid Martínez, 2011:95-118. 


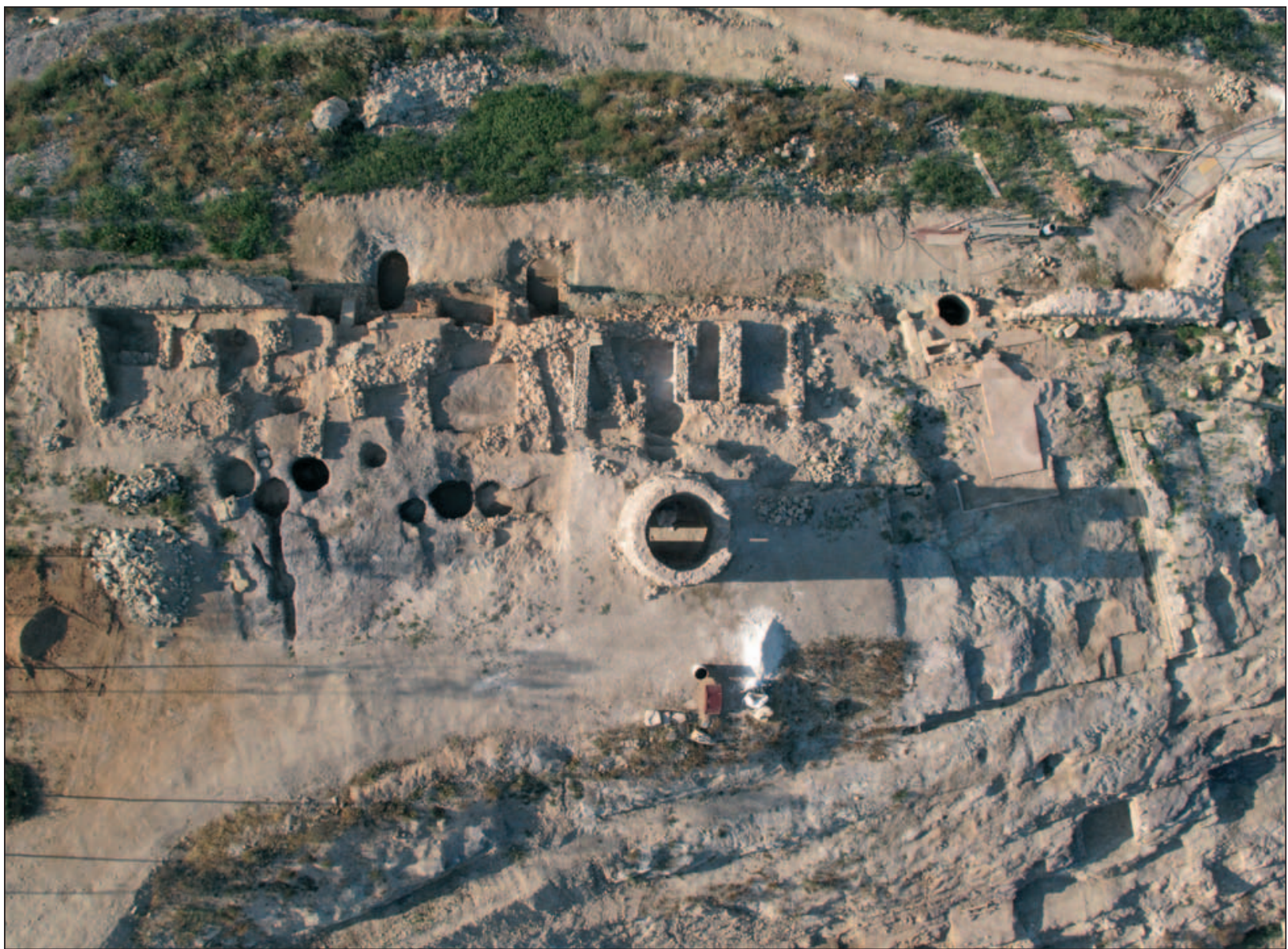

Figura 3. Parque arqueológico del Molinete. Vista aérea del área occidental del denominado sector A con los restos arqueológicos de la muralla púnica y la muralla romana superpuesta (fot. J. G. Gómez Carrasco).

XVI, no pudo consistir más que en la excavación del perfil y recorte artificial sobre el que se apoyaba la cimentación del lienzo defensivo del XVI. Por esta razón se configuró a manera de un sondeo longitudinal -de unos $40 \mathrm{~m}$ de longitud por algo más de $1 \mathrm{~m}$ de anchura-, cuyo trazado seguía el de la muralla del deán y estaba delimitado al este por los restos del santuario púnico-romano de Atargatis $^{6}$ y al oeste por la propia muralla moderna. Su flanco norte estaba limitado por la interfaz generada por los desmontes vinculados con la construcción de las viviendas que, desde el siglo XVIII, ocuparon el lado meridional de la antigua calle Vista Bella; por el sur, el sondeo estaba limi-

6 Considerado como un pequeño sacellum dedicado a la Dea Syria, después de nuestras excavaciones en la cima del cerro entre 2010-2011 sabemos que se trata, en realidad, de parte de un santuario de mayor envergadura, datable de forma genérica en el último tercio del siglo III a.C. y, por ende, perteneciente al conjunto de edificios construidos por los cartagineses en la ciudadela o acrópolis de la ciudad. Sobre tado por estructuras de grandes dimensiones, localizadas a cota superior y cimentadas en niveles asociados a materiales cerámicos de los siglos III-II a.C., interpretadas por P. San Martín como "viviendas indígenas", las cuales ahora sabemos que pertenecen, en realidad, a una muralla de casamatas de, al menos, el siglo II a.C.

Con estas metodología y limitaciones en el trabajo planteado, se ha podido documentar los restos de una construcción longitudinal de carácter unitario que, orientada de oeste a este, se alzó en la cima de la ladera septentrional del cerro y se estructuró en diversos ambientes -de los que quedan vestigios de, al menos, 12- articulados en dos

el edificio: Ramallo - Ruiz, 1994:79-102; sobre la inscripción romana en latín, escrita con teselas blancas sobre un pavimento de mortero, que facilita la información sobre la advocación del conjunto: Abascal - Ramallo, 1997:443444, n. ${ }^{\circ}$ 205; Abascal, 2004:106; Díaz, 2008:109-110, C17 (con la bibliografía anterior); Abascal, 2009:119. 


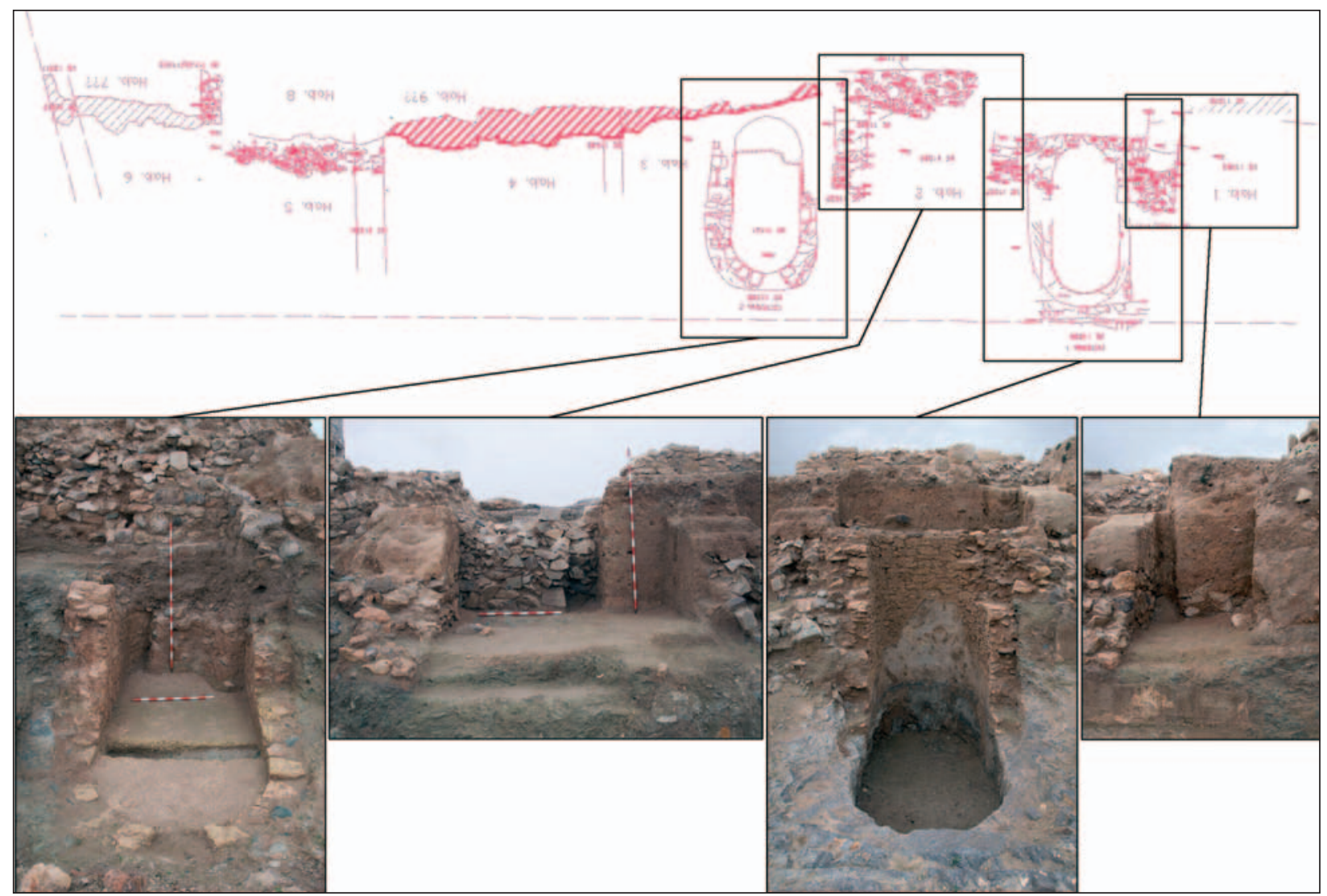

Figura 4. Planimetría de los restos arqueológicos conservados de la muralla púnica del cerro del Molinete y detalles fotográficos de los alzados (dib. M. Fuentes; comp. J. Gómez Carrasco).

planos o terrazas, y en los que, de forma alterna, se disponen, al menos, dos pequeñas cisternas del tipo a bagnarola (fig. 4). Al objeto de documentar en toda su envergadura longitudinal estas estructuras se han realizado sendas ortofotografías en planta y alzado (figs. 5-6). Las estructuras, como más adelante referiremos, están amortizadas por materiales de finales del siglo III o inicios del II a.C., pudiendo fecharse -también en atención al propio contexto histórico de la plaza- en el último treintenio de dicha centuria, en correspondencia por tanto con la fundación púnica de Qart Hadast.

El diseño y ejecución de esta estructura longitudinal parece articularse a partir de un recorte practicado en la roca de la parte alta de la ladera norte (figs. 4-5), donde se cimentó un gran muro de aterrazamiento (UUEE 11029-11031-1103311070-11091), del cual se ha documentado, en tramos discontinuos, una longitud de $28 \mathrm{~m}$; con un grosor irregular de 0,75-1 m, este paramento está integrado por un zócalo, construido con mampuestos muy irregulares y angulosos de caliza y costra caliza trabados con barro y dispuestos en hiladas de tendencia horizontal, sobre el que apoyaba el alzado realizado con adobes recubiertos, muy posiblemente, con una fina capa de mortero de cal, tal y como evidencia el ambiente $n .^{\circ} 1$. Este paramento constituye el eje vertebrador de la estructura, integrada y cimentada a norte y sur del mismo por sendos sistemas de aterrazamiento que hemos denominado terrazas inferior septentrional y superior meridional; sus límites y, por ende, dimensiones exactas son difíciles de apuntar pues las estructuras de la terraza meridional (dispuesta a una cota superior debido a la orografía de la ladera en esta zona) están arrasadas por las construcciones del siglo II a.C., mientras que las de la terraza septentrional también están seccionadas por las obras de ocupación del cerro en épocas moderna y contemporánea (muralla del deán y viviendas del siglo XVIII en adelante). El límite oriental conservado de la estructura se intuye en un muro de cuyo zócalo apenas restan algunas piedras areniscas trabadas con barro y enlazadas con el antedicho muro de aterrazamiento (UE 12217), así como en un recorte en la roca natural a partir del cual se extendió hacia el norte -en la terraza inferior- y hacia el sur -en la terraza superior-, quedando a una distancia de 


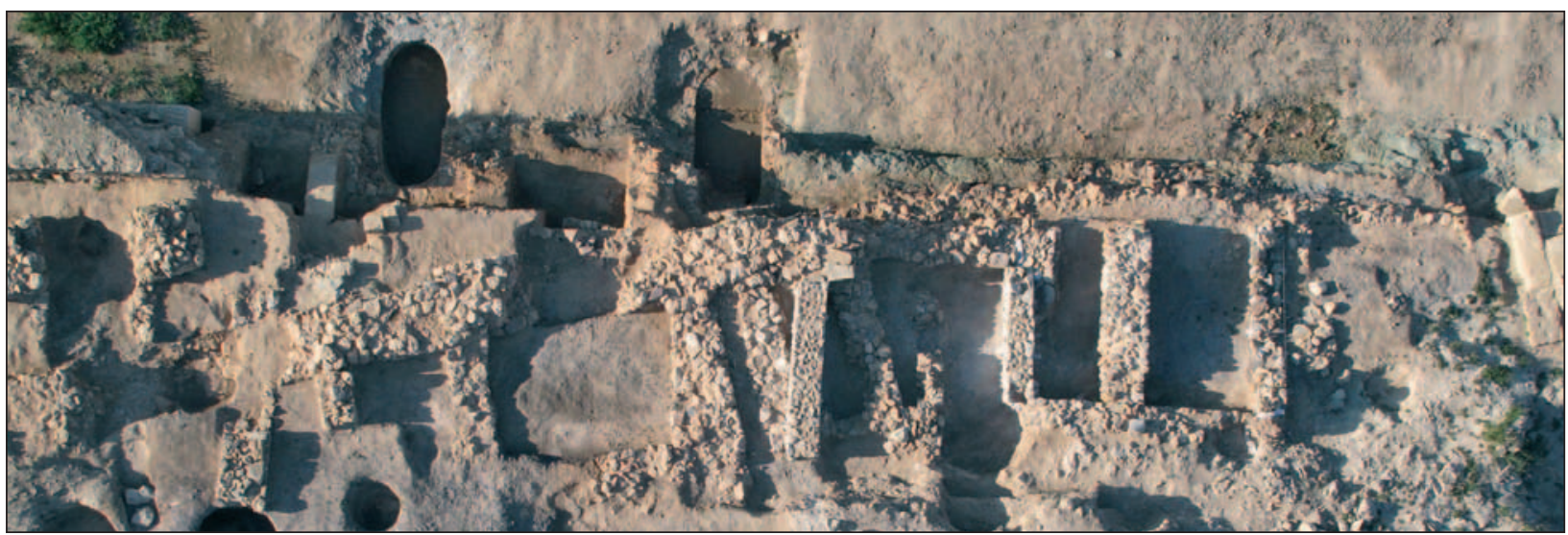

Figura 5. Ortofografía de la planta de los restos de la muralla púnica y los restos superpuestos de la muralla romana del cerro del Molinete (fot. Arqueocad).

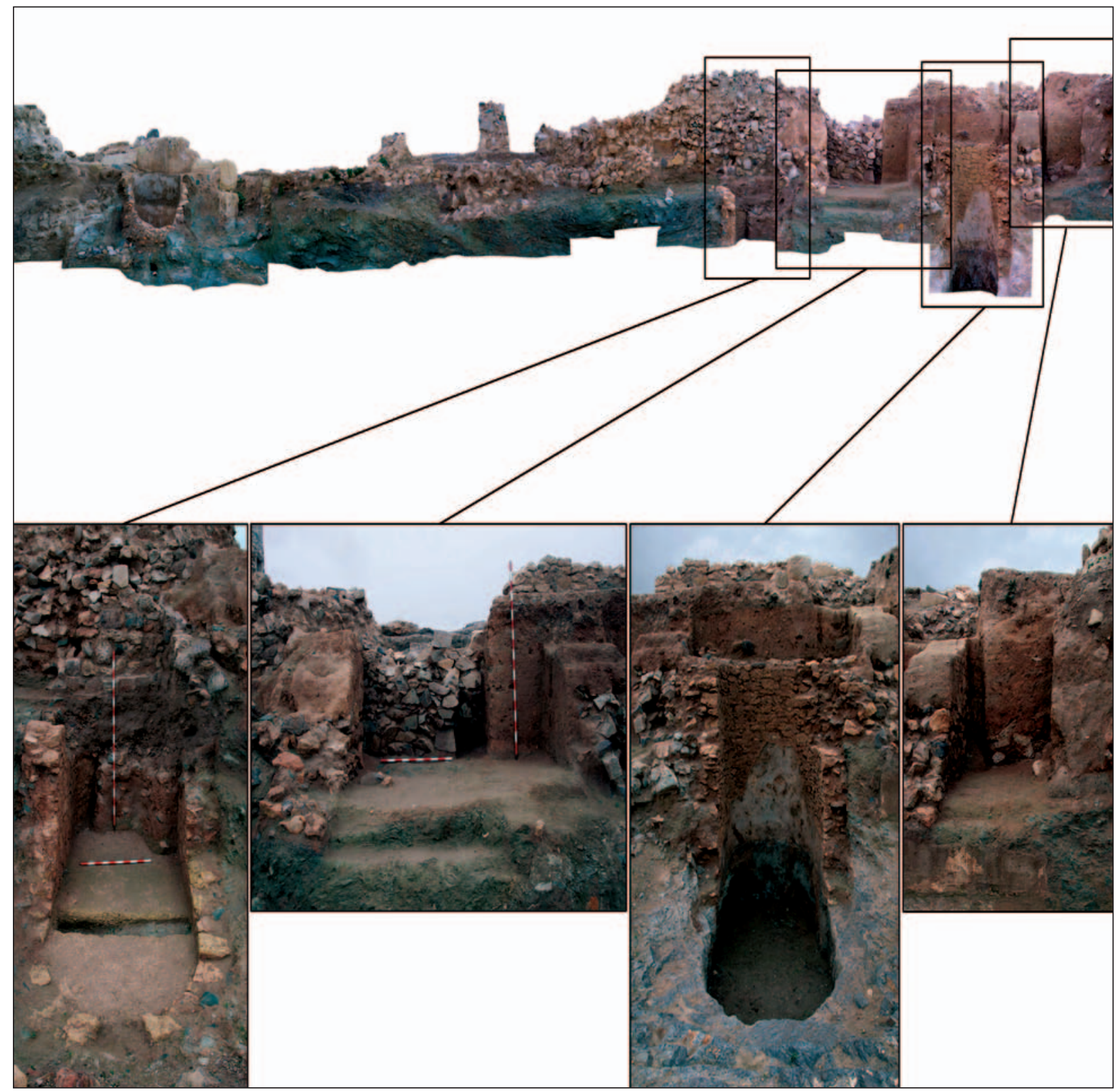

Figura 6. Ortofografía del alzado de los restos de la muralla púnica del cerro del Molinete y detalles fotográficos (fot. Arqueocad; comp. J. Gómez Carrasco). 
aproximadamente $1 \mathrm{~m}$ del santuario púnicoromano de Atargatis. Nada puede apuntarse con seguridad en relación a los límites sur de la terraza superior meridional y norte de la terraza inferior septentrional; aunque podría aventurarse que este último se sitúa a $4,85 \mathrm{~m}$ con respecto al muro de aterrazamiento, pues es la distancia existente entre el límite septentrional de las cisternas $n .^{\circ} 1$ y 2 , localizadas en esta terraza inferior, y el muro de aterrazamiento. Tampoco pueden apuntarse datos sobre el límite occidental de la estructura, seccionada en esta zona por construcciones de épocas posteriores; en todo caso, las estructuras de los ambientes $\mathrm{n} .{ }^{\circ} 10$ y 1 marcan, por ahora, el límite occidental de las terrazas superior meridional e inferior septentrional, respectivamente, sin que sea factible avanzar más en la investigación arqueológica de esta zona ocupada por la cimentación y alzados de la muralla del deán.

Como ya hemos referido, la información sobre la configuración arquitectónica de la terraza superior meridional es muy escasa e, incluso, está muy descontextualizada desde el punto de vista estratigráfico al haber sido buena parte de sus estructuras ya excavadas por San Martín en 1977-78, pudiéndose definir de forma clara la existencia de sendos ambientes en sus extremos oriental y occidental (n. 7 y 10 , respectivamente). El primero de ellos, ubicado a escasa distancia del santuario de Atargatis, está delimitado al norte por el muro de aterrazamiento ya referido (UE 11033), al este por los restos del muro UE 12217, y al oeste por la estructura UUEE 11130-11032, de unos 0,50 m de anchura, construida con pequeños mampuestos de caliza y costra caliza trabados con barro y asentados sobre la roca natural regularizada; del cierre meridional no se conserva ninguna estructura, aunque el propio declive de la roca natural parece conformar una suerte de límite del espacio $\mathrm{n}^{\circ} 7$ ). Con esta información, puede postularse la existencia de un ambiente de $c a .2,85 \mathrm{~m}$ de anchura -en función de sus paramentos occidental y oriental- por $c a .2,5 \mathrm{~m}$ de longitud. No queda constancia arqueológica, por el momento, de una sucesión de ambientes en este plano hacia el oeste, pues no puede confirmarse arqueológicamente la continuidad del paramento UE 11034 hacia la terraza superior sur; así lo impiden en esta zona la presencia de un muro de época augustea (UE 11133) y los recortes y vaciados asociados a la construcción de la muralla del siglo XVI. En todo caso, el paramento del siglo I (UE 11133) que sigue la misma orientación y posición marcada por el púnico en la terraza inferior sur, resulta cuanto menos, revelador al respecto. Por otro lado, observando en detalle la técnica constructiva de los paramentos identificados en la terraza superior meridional, advertimos cómo otro muro del siglo I (UE 11249) muestra en su base una primera hilada de mampuestos de diverso formato y menor tamaño, trabados con barro, apoyados sobre la roca natural y ligeramente sobresalientes respecto al alzado superior; dada la ausencia de estratigrafías asociadas, es difícil precisar su cronología, aunque cabe la posibilidad, dado que el tamaño y orientación de los mampuestos coincide con los usados en época púnica, que pueda tratarse de los restos de un muro púnico asociable, así pues, a la terraza superior meridional de la estructura objeto de análisis.

Por último, en el extremo más occidental de la terraza se constatan restos correspondientes al posible ambiente $n .^{\circ} 10$. Se trata del ángulo formado por sendos muros -oriental (UE 11165) y meridional (UE 11166) - con zócalos construidos también con piedras pequeñas y medianas trabadas con barro; ambas estructuras están seccionadas por una fosa que parece vincularse a la construcción de la muralla del deán, aunque la ausencia de estratigrafías asociadas obliga a ser cautos al respecto pues su orientación coincide con el trazado del muro de aterrazamiento principal. En todo caso, la técnica constructiva empleada en estos paramentos responde a la de las estructuras de época púnica.

Referente a la terraza inferior septentrional, a la que más directamente afectaron los recortes y cimentaciones de la muralla del deán y a pesar de la parcialidad de los restos conservados, se ha podido documentar diversas estructuras de gran interés y los contextos estratigráficos a ellas asociados (fig. 7). La excavación de los niveles en que apoyaba la cimentación de la muralla del siglo XVI ha permitido identificar estructuras correspondientes a varios ambientes (en algunos de los cuales no se han hallado niveles de uso asociados), concatenados de oeste a este y orientados de norte a sur, todos trabados con la fábrica del muro de aterrazamiento principal ya referido. De este a oeste, se ha constatado, en primer término, los vestigios del ambiente $n .{ }^{\circ} 6$, delimitado al sur por el muro de aterrazamiento UE 11033, que articula toda la estructura y del que apenas se conservan en esta zona algunos mampuestos dispues- 


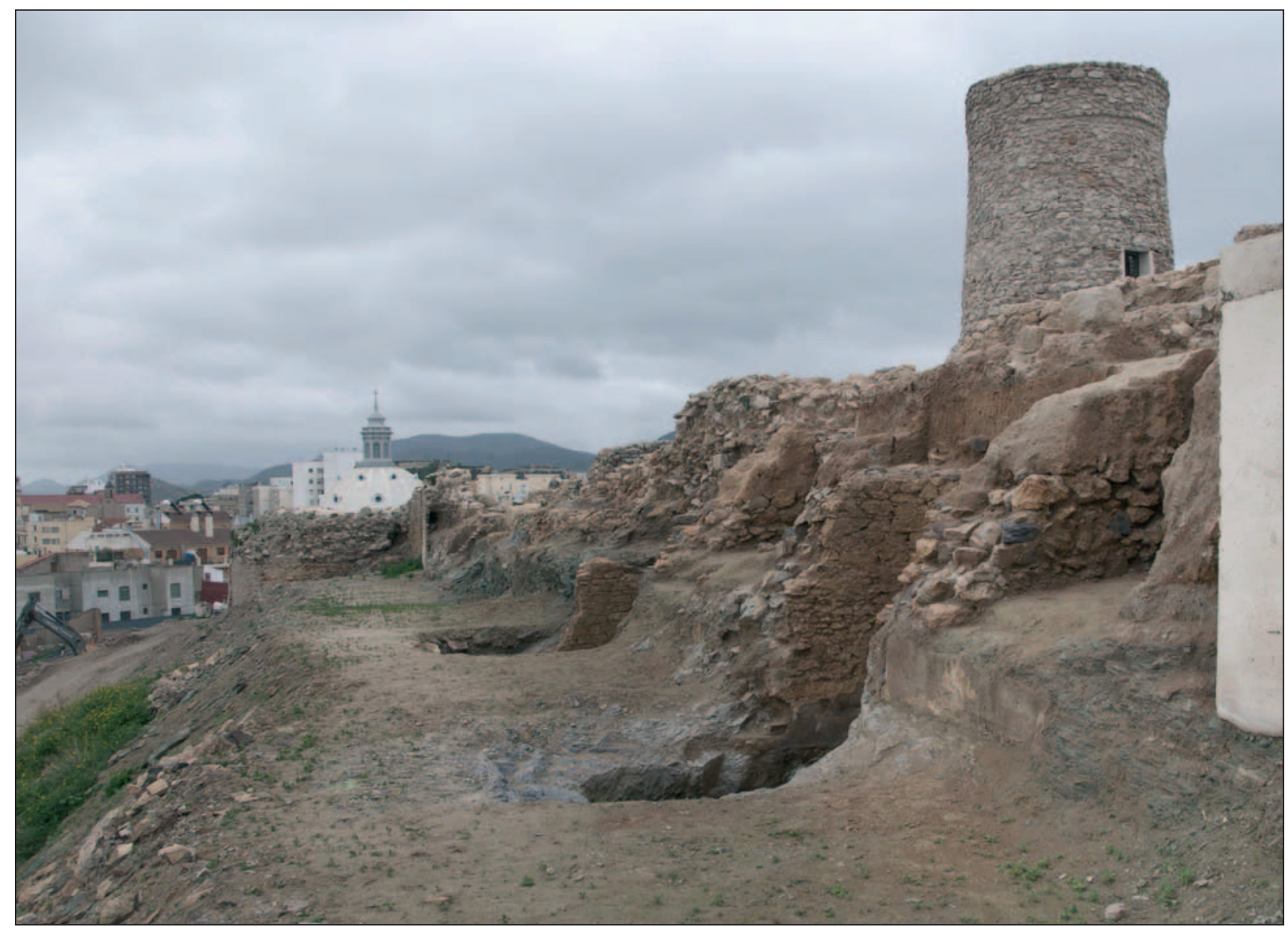

Figura 7. Perspectiva desde el noroeste de los ambientes $n .^{\circ} 1$ y 2 y de la cisterna $n .^{\circ} 1$ de la muralla púnica (fot. J. Gómez Carrasco).

tos sobre la roca natural tallada y regularizada; enlazando con este paramento, se han localizado sus muros este (UE 12217) y oeste (UE 11032) -ya referidos al describir el ambiente n. 7 de la terraza superior sur-. Aunque no se ha podido documentar las dimensiones totales del ambiente, pues su zona más septentrional está seccionada por los recortes practicados para la construcción de una de las viviendas de la antigua calle Vista Bella, parece tratarse de un espacio de planta trapezoidal, construido a apenas $1 \mathrm{~m}$ del santuario de Atargatis. El referido muro oeste (UE 1113011032) hace las veces de medianero con el ambiente $n .^{\circ} 5$, del que apenas se conserva parte del muro meridional (UE 11033) y el inicio -perfectamente trabado con la fábrica del anterior- del occidental (UE 11034), construido también con mampostería junteada con barro. Se trata de una estancia de unos $3 \mathrm{~m}$ de anchura y de longitud desconocida por haber sido su límite septentrional completamente seccionado por las viviendas de época contemporánea. El análisis de los caracteres constructivos del muro UE 11034 sugiere la eventualidad de que, en realidad, se prolongase en la terraza superior meridional, configurando de esta forma la existencia de otro hipotético ambiente (n. $\left.{ }^{\circ} 8\right)$ de igual anchura.

$\mathrm{Al}$ oeste y adyacente al $n .^{\circ} 5$, se alza el ambiente . $^{\circ} 4$, delimitado al este por el paramento UE 11034 ya referido, al sur por el muro de aterrazamiento principal (UE 11033) del que apenas se conservan algunos mampuestos muy descohesionados a causa de la fractura producida por la construcción de la muralla del deán, y al oeste por el paramento UE 11036, del que se ha podido identificar en el perfil de excavación parte del muro seccionado (figs. 8-9). Se trata de un espacio de $c a .5 \mathrm{~m}$ de anchura por una longitud indeterminada en sentido norte-sur, pues no se conserva el muro que lo cerraría por el norte. Si admitimos la posibilidad de que la hilada inferior del muro augusteo identificado en la terraza superior (UE 11249) correspondiese en origen a la fase constructiva púnica y que se proyectase en la terraza inferior, algo que parece advertirse al estudiar en detalle el ortofotoplano del muro de ate- 


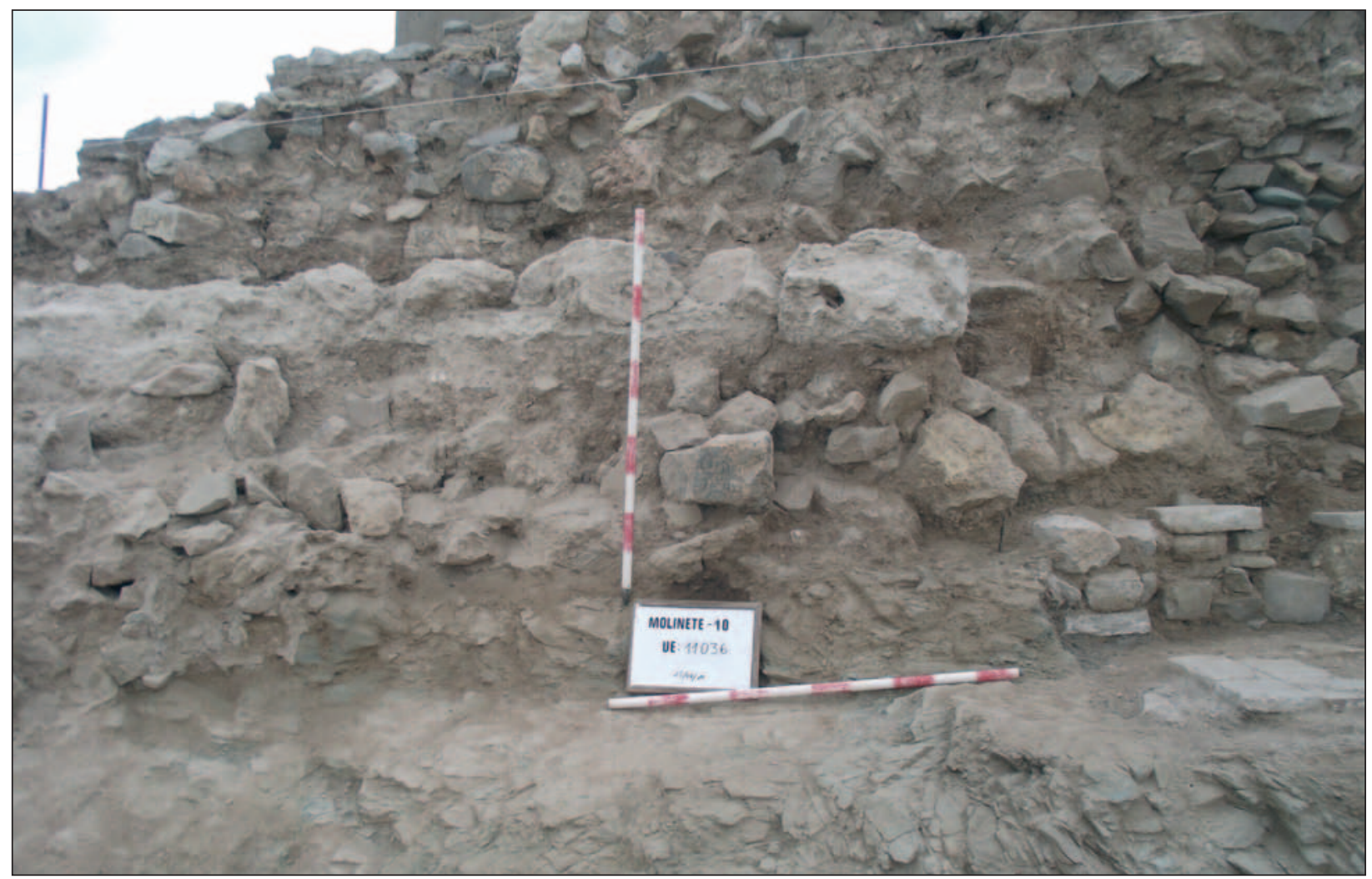

Figura 8. Vista del ambiente n. $^{\circ} 4$ de la muralla púnica, con detalle del alzado de la UE 11036 durante el proceso de excavación (fot. M. ${ }^{\mathrm{a}}$ J. Madrid).

rrazamiento principal, el ambiente n. ${ }^{\circ} 4$ tendría una anchura de unos $3 \mathrm{~m}$, existiendo entonces un estrecho espacio (acaso un paso o caja de escalera?) entre los ambientes $n .^{\circ} 4$ y 5 que permitiría la comunicación entre ambas terrazas.

$\mathrm{Al}$ oeste del ambiente . $^{\circ} 4$ se dispone el n. ${ }^{\circ} 3$, del que sólo pueden referirse algunos escasos datos planimétricos, pues una casa de la antigua calle Vista Bella adosada a la muralla del siglo XVI había destruido por completo en esta zona todo el depósito estratigráfico (fig. 10). En cualquier caso, pudo configurarse como un espacio de unos $2 \mathrm{~m}$ de anchura, delimitado al este por el muro medianero del contiguo ambiente $n .{ }^{\circ} 4$ (UE 11036), al sur por el muro de aterrazamiento principal UE 11033 y al oeste por las estructuras de la cisterna n. $^{\circ} 2$ (UE 11039); como en el resto de ambientes, no queda evidencia material alguna concerniente al muro de cierre septentrional.

A continuación se dispone la cisterna . $^{\circ} 2$ (fig. 11), uno de los elementos más interesantes y significativos del complejo junto con la $\mathrm{n} .^{\circ} 1$. Se trata de un depósito a bagnarola (UE 11039), de planta rectangular y lados menores absidados (Egea, 2003:112, tipo II.2), excavada parcialmente en el terreno natural y construida con muros, de

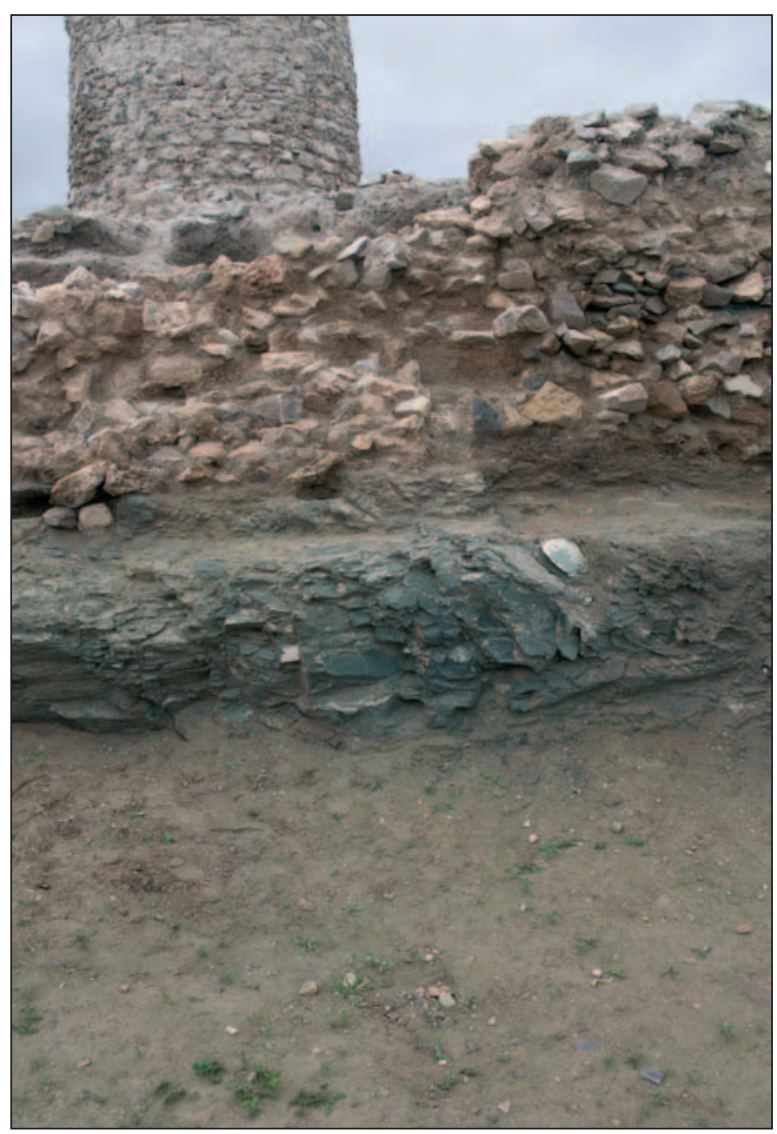

Figura 9. Vista del ambiente $\mathrm{n}^{\circ} 4$ de la muralla púnica (fot. J. Gómez Carrasco). 


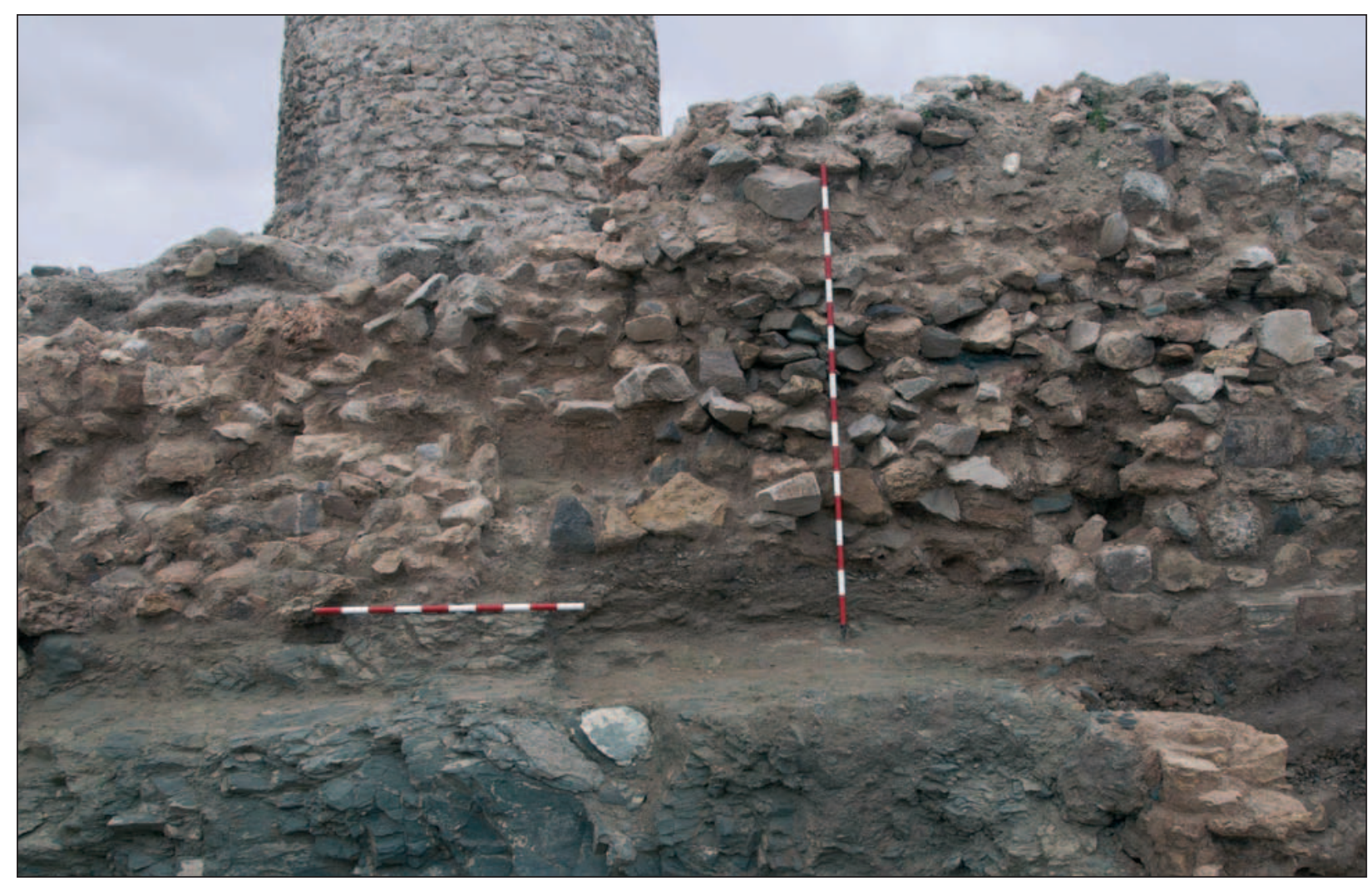

Figura 10. Vista del ambiente n. ${ }^{\circ} 3$ de la muralla púnica (fot. J. Gómez Carrasco).

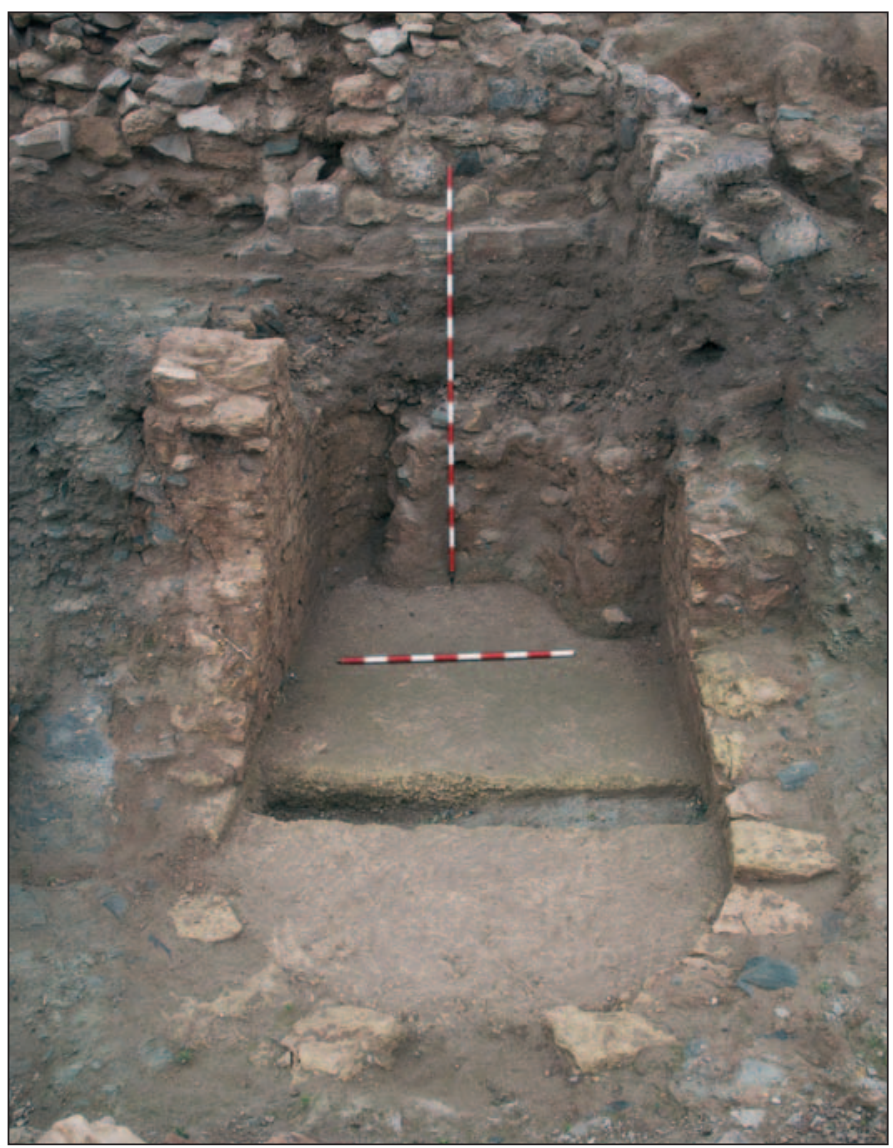

Figura 11. Vista de la cisterna n. $^{\circ} 2$ de la muralla púnica (fot. J. Gómez Carrasco). 


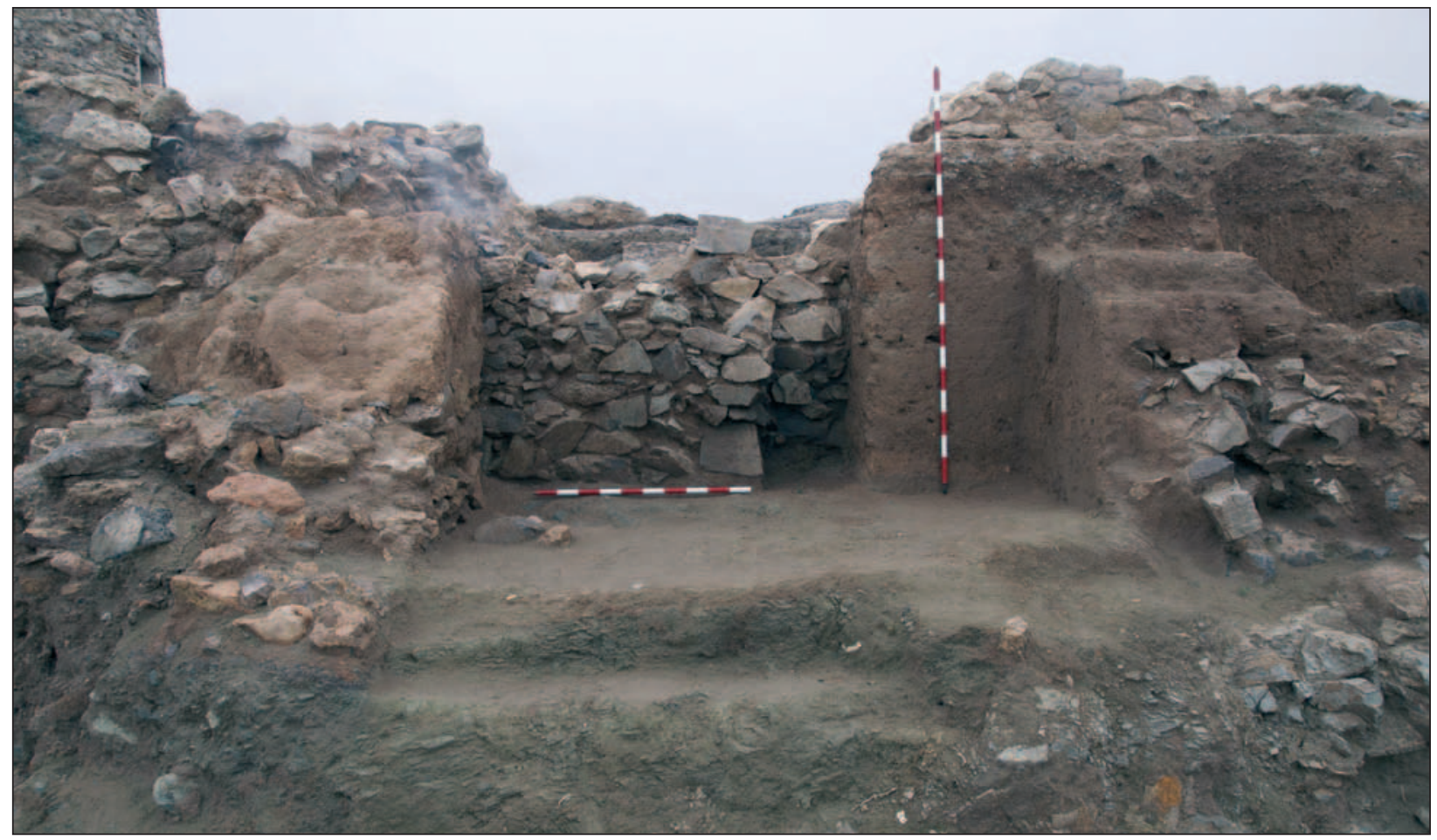

Figura 12. Vista del ambiente n. ${ }^{\circ} 2$ de la muralla púnica (fot. J. Gómez Carrasco).

0,30 $\mathrm{m}$ de espesor y realizados con mampuestos trabados con barro entre los que destaca el empleo mayoritario de piedra caliza menuda, costra caliza y areniscas dispuestas en hiladas de tendencia horizontal. Esta cisterna de tipo helenístico, de $3,50 \mathrm{~m}$ de longitud por 1,50 $\mathrm{m}$ de anchura, estaba enlucida al interior mediante una capa impermeable de mortero hidráulico de cal, de tonalidad amarillenta y abundantes fragmentos de cerámica machacada de pequeño calibre (UE 11161); el fondo, que estaba impermeabilizado con el mismo tipo de mortero, estaba a $c a \cdot 1,80 \mathrm{~m}$ por debajo de la cota de circulación de los ambientes de la terraza inferior norte. El depósito está inserto en una dependencia de planta rectangular que lo envuelve y delimita por completo: por el sur estaba delimitado por el muro de aterrazamiento principal que articula todo el complejo (UE 11033), y por el oeste por un muro de mampostería y tapial (UE 11026); sus estructuras septentrional y suroriental fueron seccionadas y destruidas por la construcción de una vivienda del siglo XVIII adosada al paramento norte de la muralla del deán. Respecto al depósito arqueológico del interior de la cisterna, estaba colmatado por tierra arcillosa de tonalidad marrón clara, compacta y con pintas de cal y carboncillos (UE 11049), que no ha aportado material cerámico; de ahí que nada pueda señalarse sobre su fecha de amortización.
Más al oeste, se documentan los vestigios del ambiente $n .^{\circ} 2$, encajado entre las cisternas $n .^{\circ} 1 \mathrm{y}$ 2 (fig. 12), sirviendo de medianera con cada una de ellas los muros UUEE 11026 y 11027, ambos de unos $0,70 \mathrm{~m}$ de anchura, construidos con zócalos de mampostería y alzados de tapial/adobes que, en algunos puntos, conservan aún restos de lo que podría interpretarse como un enlucido formado por una fina capa de cal. El ambiente n. ${ }^{\circ} 2$ está delimitado por el sur por el muro de aterrazamiento principal que articula todo el complejo (UE 11091), de unos 0,74 $\mathrm{m}$ de anchura, construido con hiladas muy irregulares de mampuestos trabados con barro. Este grueso paramento debió debilitarse como consecuencia de los empujes tectónicos de la construcción, por lo que parece haber sido reparado o reforzado con un nuevo tramo de mampostería adosado, de factura y dimensiones muy irregulares (UE 11092) y cimentado sobre la propia roca natural.

$\mathrm{Al}$ oeste, encajada entre los muros UUEE 11027 y 11023 , correspondientes a los ambientes n. 2 y 1 , se dispone la cisterna n. ${ }^{\circ} 1$ (UE 11038) (fig. 13), del tipo helenístico a bagnarola y planta rectangular con ábsides contrapuestos; el depósito se inscribe en una estructura rectangular identificada en la mampostería que maciza el espacio comprendido entre su límite meridional y los muros perimetrales, como en el recorte rectilíneo 


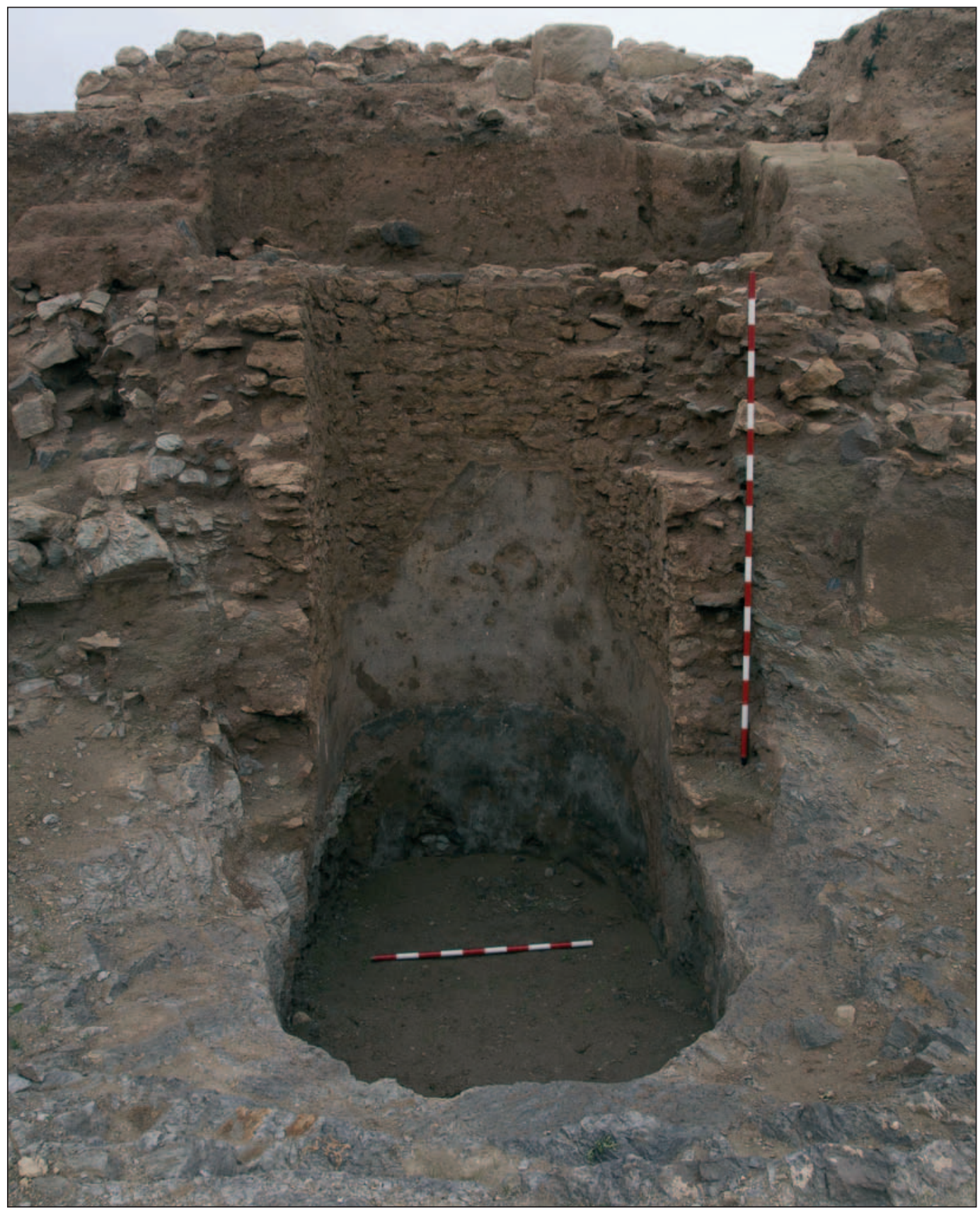

Figura 13. Vista de la cisterna n. ${ }^{\circ} 1$ de la muralla púnica (fot. J. Gómez Carrasco).

que se advierte en la roca natural, junto al extremo norte, también con restos de mampostería asociada; dichos vestigios constituyen, por el momento, la única evidencia concerniente a la posición exacta del muro de cierre septentrional de la estructura. Las dimensiones interiores de la cisterna son 3,22 $\mathrm{m}$ de longitud y 1,52 $\mathrm{m}$ de anchura, mientras que al exterior la estructura perimetral en que se encaja mide 4,11 m de longitud por 2,77 $\mathrm{m}$ de anchura. La técnica constructiva empleada es, como en el caso de la cisterna $n .^{\circ}$ 2 , mampostería irregular trabada con barro, orga- nizada en la cara interna en hiladas muy regulares de piedra arenisca, de tamaño menudo y trabada con capas espesas de barro; esta mampostería forra incluso la parte inferior de la cisterna, excavada en la roca natural. La cisterna se empleó hasta el siglo XX, razón por la cual su fondo está roto y horadado; no obstante, persisten evidencias de su suelo original en el enlucido de los muros que la cierran por el sur, apreciándose -como en el caso de la cisterna $n$. $^{\circ}$ - una diferencia de cota destacada entre el suelo de los ambientes adyacentes y el fondo del depósito. Su reutilización 
como aljibe de agua para uso doméstico hasta época reciente es la causa de su conservación completamente seccionada, recubierta al interior por una capa de cemento que, en ocasiones, se adhiere al enlucido de mortero hidráulico original, y totalmente colmatada por basuras de diversa índole y naturaleza; todo lo cual ha destruido por completo el depósito arqueológico original.

Por último, en el extremo más occidental del sondeo, y en parte situado bajo la muralla del deán, se ha constatado el ambiente n. ${ }^{\circ} 1$ (fig. 14), del cual se ha podido identificar el muro oriental (UUEE 11023-11071) que, al igual que el del ambiente $n .^{\circ}$ 2, tiene una anchura de $c a .0,70 \mathrm{~m}$; cimentado sobre la roca natural, está compuesto por un zócalo, de mampostería irregular trabada con barro, recrecido mediante un alzado de tapial/adobe que, en algunos casos, conserva restos de lo que pudo ser un fino enlucido de cal. La duda relativa a si el alzado se construyó de tapial o adobe deriva de que no se advierte con claridad la presencia de los segundos, si bien en los niveles de derrumbe hallados en su interior sí se han hallado restos de ellos. El cierre meridional apenas se ha podido constatar en una pequeña sec- ción, pues las cimentaciones de la muralla del deán y un muro de grandes dimensiones del siglo II a.C. -que apoya en esta terraza- han imposibilitado concluir la excavación del ambiente. En todo caso, como en el caso de los precedentes, el ambiente está seccionado y destruido al norte por las viviendas de la antigua calle Vista Bella.

Como puede apreciarse, el estado de conservación de esta estructura longitudinal púnica es muy parcial, pues ha sido cortada y seccionada en varios momentos, lo que ha implicado la destrucción de buena parte de sus alzados. Primero, en época romana, con ocasión de la construcción de un paramento de grandes dimensiones en la cima de la colina. Más tarde, ya en el siglo XVI, al ejecutarse las obras cimentación y construcción de la cortina de la muralla del deán, que asentaba directamente los muros de esta estructura. Por último, entre los siglos XVIII y XIX, como consecuencia del trazado de la calle Vista Bella y, en particular, de la construcción de las viviendas que entonces se adosaron a la cara norte de la muralla moderna, cortando y seccionando nuevamente las estructuras púnicas y su depósito arqueológico asociado.

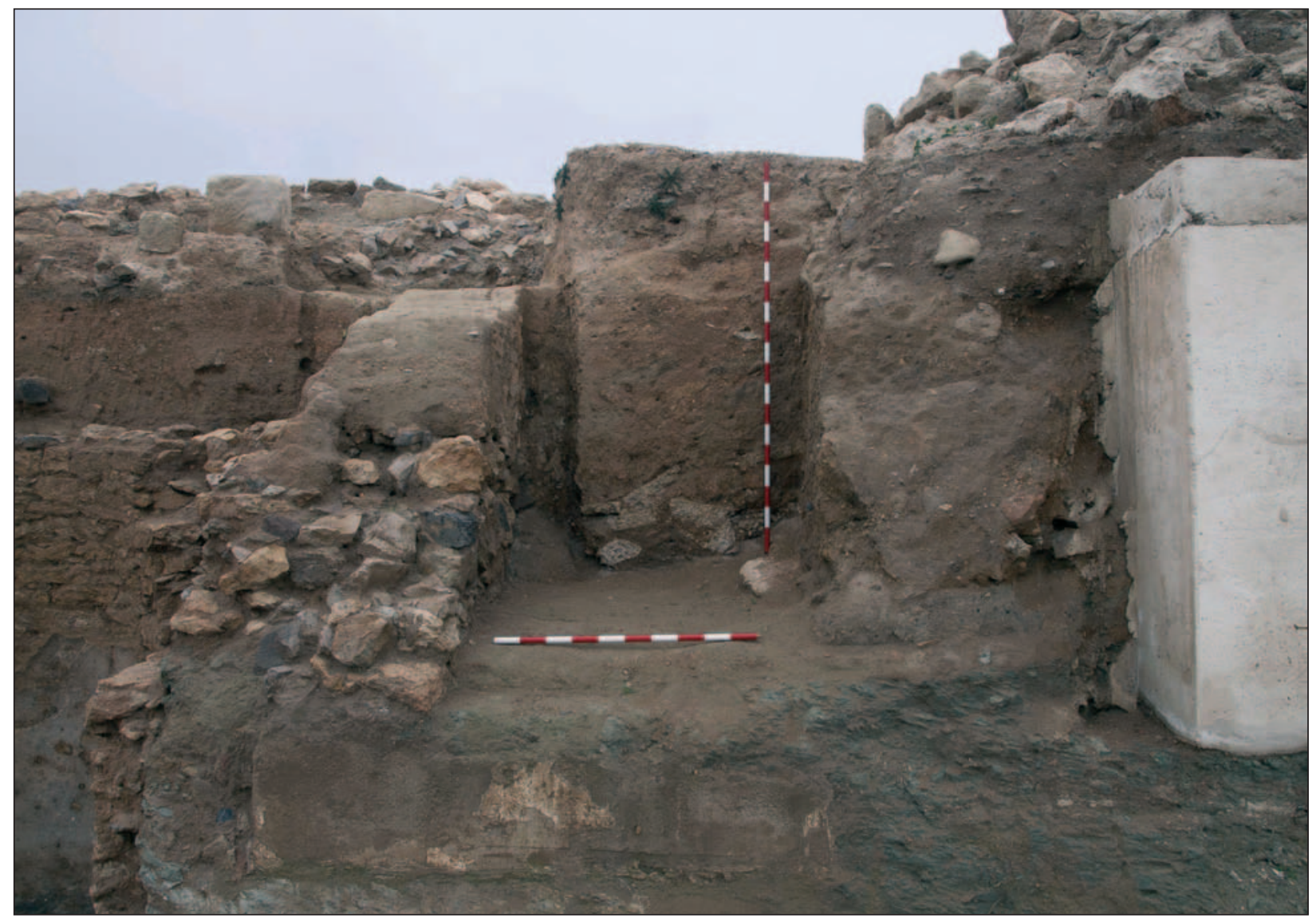

Figura 14. Vista del ambiente n. ${ }^{\circ} 1$ de la muralla púnica (fot. J. Gómez Carrasco). 
En todo caso, las evidencias documentadas corresponden a una estructura arquitectónica de formato longitudinal, construida en la cima de la vertiente septentrional del cerro, y organizada a partir de un muro de aterrazamiento principal al norte y sur del cual se dispusieron sendas terrazas, en la superior de las cuales se han constatado, al menos, 3 ambientes, y en la inferior 6 ambientes y 2 cisternas para almacenamiento de agua. Como veremos, unas y otras podrían corresponder a un conjunto de substrucciones que, vistas por el alzado de su frente septentrional, configurasen una estructura de planta longitudinal -conservada en, al menos, $28 \mathrm{~m}$ - construida mediante la técnica de doble paramento con espacios internos ejecutados mediante muros perpendiculares, concebidos a modo de tirantes y dispuestos a intervalos regulares. Como más adelante argumentaremos, podría identificarse tipológicamente con una muralla de casernas o casamatas que formara parte del sistema defensivo que, hacia el lado del Almarjal o laguna interior, protegía tanto la ciudad como la arx de la fundación púnica, es decir, la ciudadela donde Hasdrúbal -a decir de Polibiohabía construido su palacio. Pero antes de ampliar nuestro argumento, analicemos la información estratigráfica asociada a dichas estructuras y los datos para encuadrarlas en la diacronía histórica.

\section{ESTRATIGRAFÍA Y CONTEXTOS CERÁMICOS}

Durante la excavación del referido sondeo no se ha constatado nivel estratigráfico alguno asociable a la construcción de estas estructuras arquitectónicas. Sin embargo, al menos a los ambientes $n .^{\circ} 1$ y 2 se asocia una interesante secuencia estratigráfica que coadyuva de manera decisiva a su fechación e interpretación arquitectónica. Así, en el ambiente n..$^{\circ} 2$ se ha documentado, dispuesta directamente sobre la roca natural regularizada, una capa de arcilla apisonada (UE 11090) correspondiente al suelo de la dependencia; sobre este piso se constató parte de un estrato (UE11086) compuesto por carboncillos y grandes fragmentos de mortero (opus signinum), caídos directamente sobre el suelo, y trozos de adobes y tierra procedentes de los alzados, que pueden interpretarse como el derrumbe de los alzados y la cubierta plana de la construcción, la cual permitiría la recogida de aguas y su canalización hacia el interior de las cisternas. También en el ambiente $n .^{\circ} 1$ el nivel de circulación y uso está integrado por una capa de barro apisonado (UE 11093), el cual está amortizado por varios estratos (UUEE 1107611077) compuestos por numerosos trozos de mortero (opus signinum), restos de adobes, algunas piedras de mediano y pequeño tamaño, carboncillos y fragmentos de ánforas (fig. 15); dichos estratos y sus materiales corresponden al colapso de la cubierta y alzados del ambiente, que acaeció de forma violenta a tenor de los caracteres del depósito arqueológico registrado. De hecho, cubierto por estos estratos de derrumbe, y directamente depuesto sobre la cota de circulación del ambiente, se documentó un estrato con abundantes carbones y cenizas (UE 11088) (fig. 16) que puede interpretarse como un nivel de incendio vinculado a la destrucción de esta estructura.

Los materiales, en particular cerámicos, presentes en estos niveles de derrumbe y destrucción, pese a ser escasos desde el punto de vista cuanti-

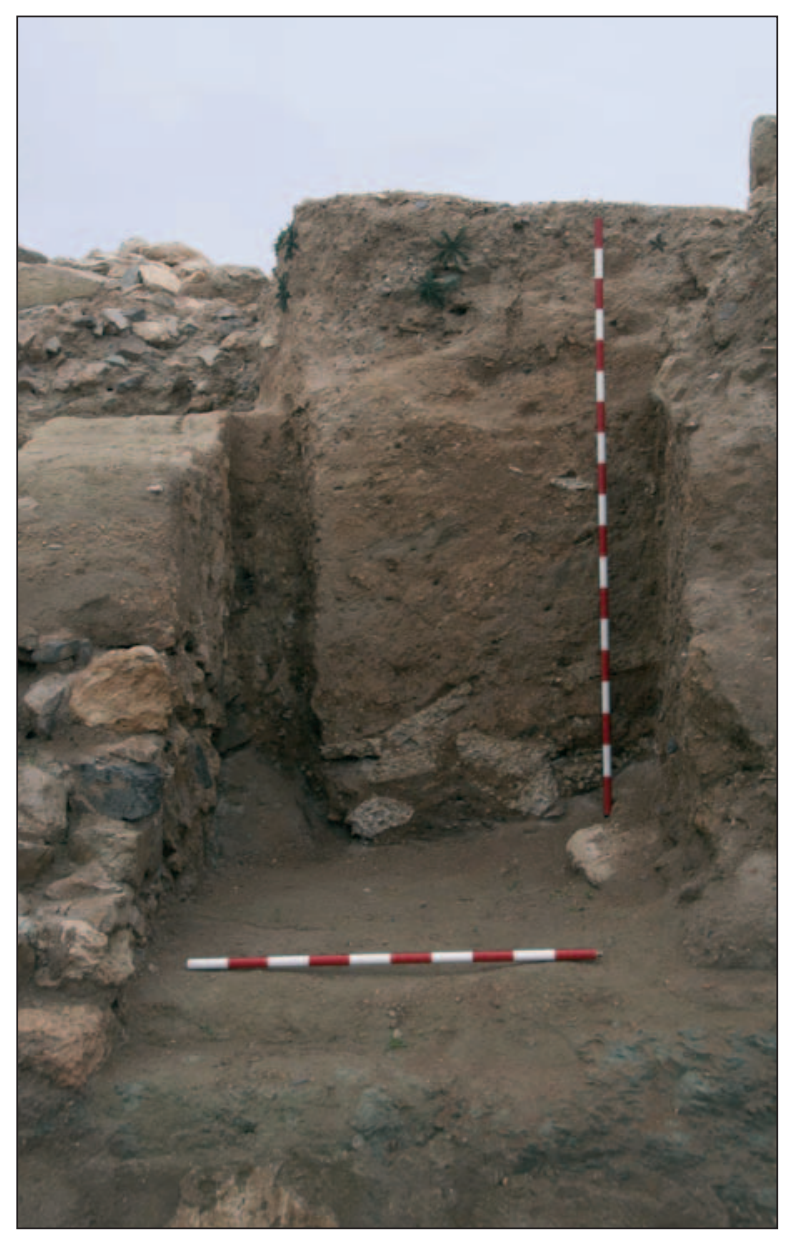

Figura 15. Vista del perfil de excavación del depósito arqueológico sobre el pavimento del ambiente n. ${ }^{\circ} 1$ de la muralla púnica, donde se aprecian caídos los adobes disueltos y los restos de mortero hidráulico de la techumbre (fot. J. Gómez Carrasco). 


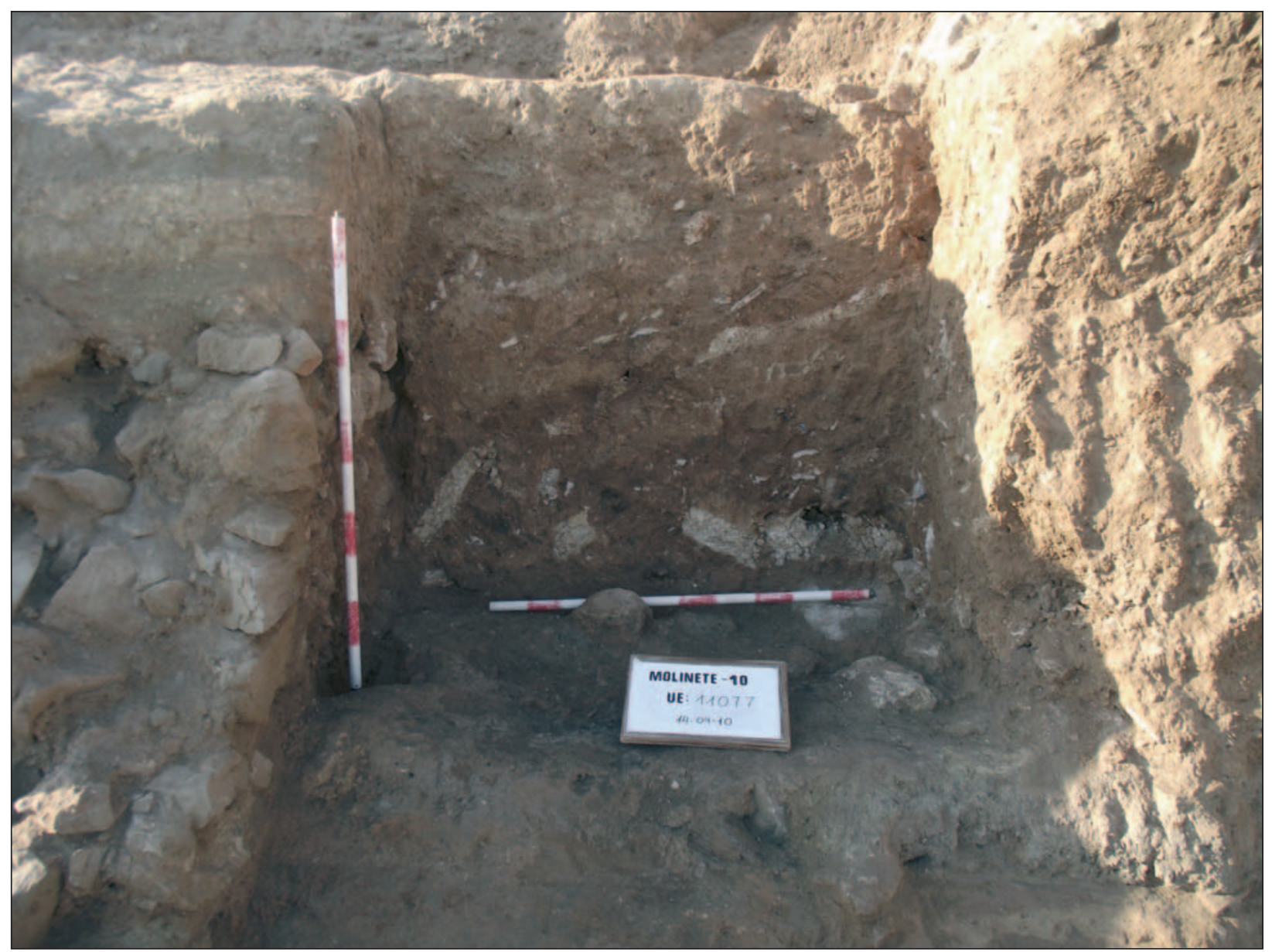

Figura 16. Nivel de incendio integrado por carbones y cenizas (UE 11088) depuesto sobre el pavimento del ambiente . $^{\circ} 1$ de la muralla púnica (fot. M. ${ }^{\mathrm{a}}$ J. Madrid).

tativo, constituyen un magnífico testimonio de los contextos cerámicos asociados a la ciudad bárquida de las últimas décadas del siglo III a.C. En los derrumbes constatados en el interior de los ambientes n.o 1 y 2 (UUEE 11076, 11077 y 11086), la vajilla fina de mesa está compuesta mayoritariamente por cerámicas itálicas importadas de barniz negro, destacando en primer término las producciones de Campaniense A, representadas por varios fragmentos informes, un fondo y un borde de cuenco del tipo Lamb. 27 (fig. 17.1), a las que deben sumarse un pequeño fragmento de producción Calena. Destaca también otro un grupo, más heterogéneo, de cerámicas barnizadas con pastas grisáceas, a las que con frecuencia se asigna un origen ebusitano, con un repertorio formal compuesto por un plato asimilable a una forma Lamb. 27 (fig. 17.3), un cuenco carenado con borde de tendencia vertical (fig. 17.2) similar a la forma ebusitana HX-1/53 (Ramón, 1994:fig. 9.53), y una copa de borde exvasado y engrosado al exterior (fig. 17.4) semejante al tipo HX-1/52, fechado como el anterior entre 240 y 210 a.C. (Ramón, 1994:fig. 9.52); estas producciones se constatan también en algunos niveles de destrucción de la ciudad púnica a finales del siglo III a.C. (Martín - Roldán, 1997:lám. IV.30; Ramallo Ruiz, 2009:fig. 7.539). Las producciones ibéricas se limitan a unos cuantos fragmentos informes de cerámicas decoradas con motivos pintados geométricos de bandas y círculos concéntricos, y a algunas cerámicas de cocina, sobre todo ollas de cocción reductora (fig. 17.5). Entre el resto de la vajilla constatada destaca un pequeño fragmento de labio de perfil ondulado perteneciente a un mortero de fabricación ebusitana (Guerrero, 1996:208-210) (fig. 17.6) -producción igualmente presente en contextos bárquidas de la ciudad (Martín - Roldán, 2000)-, hallado junto a varios fragmentos informes de cerámicas comunes de producción norteafricana. Relativo a las producciones vinculadas con la iluminación, sólo hay un fragmento, bastante completo, de una lucerna de barniz negro de tipo helenístico, caracterizada por 


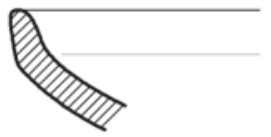

1

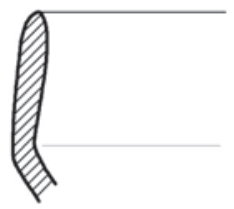

2
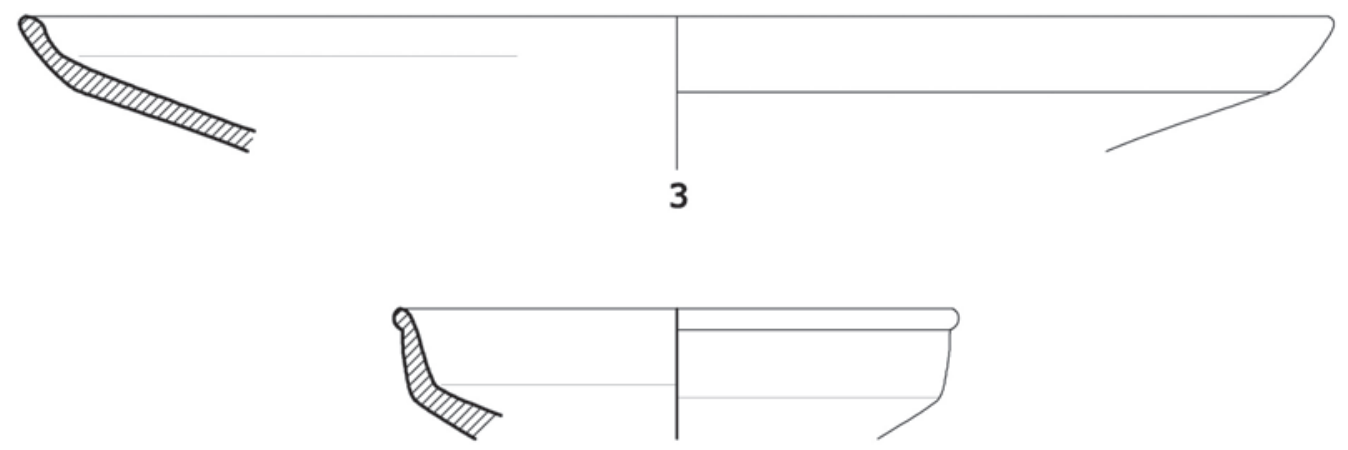

4
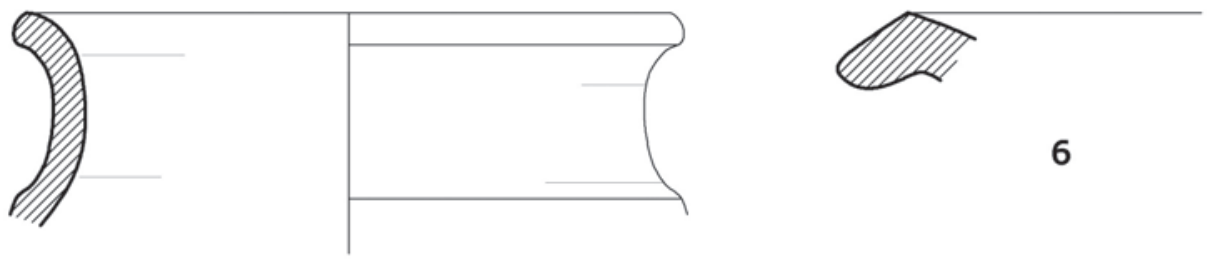

6

5
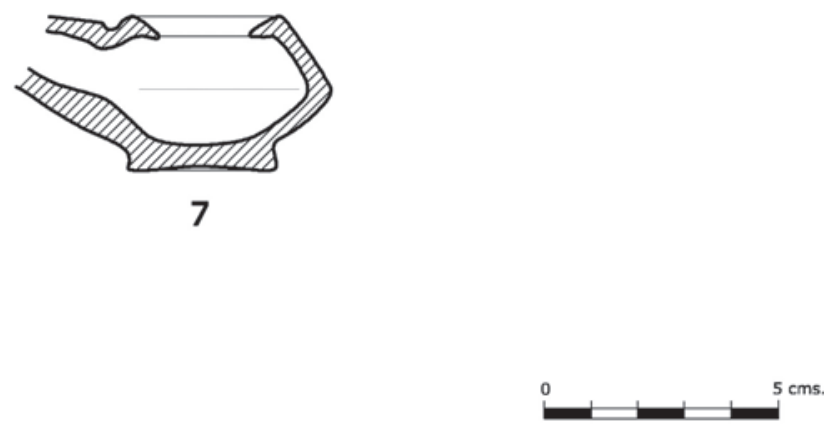

Figura 17. Material cerámico procedente de los estratos de amortización (UUEE 11076, 11077 y 11086 ) que amortizaban los ambientes n. ${ }^{\circ} 1$ y 2 de la muralla púnica (dib. S. Pérez-Cuadrado Martínez).

mostrar un cuerpo de perfil troncocónico con el pie realzado de base cóncava (fig. 17.7), muy semejante al tipo Ricci B (Ricci, 1974). Respecto a las ánforas, cabría destacar primero las procedentes del área del Círculo del Estrecho, representadas por un borde de Maña-Pascual A-4 (fig. 18.1) y un ánfora cilíndrica del tipo T-4.2.2.5 (fig. 18.2), cuyo momento álgido de producción se sitúa entre 225 y 175 a.C. (Ramón, 1995:194); estas producciones están bien documentadas en el vertedero de la plaza de San Ginés (Martín, 1998:lám. III.12) y en el nivel de destrucción de la calle Saura (Ramallo - Ruiz, 2009:fig. 7.539); esta categoría funcional se completa con una fragmento de Maña D de producción tunecina (fig. 18.3), tipo T-5.2.3.1 de J. Ramón, cuya cronología se extiende entre el último cuarto del siglo III y el primer cuarto del II a.C. (Ramón, 1995:198). 


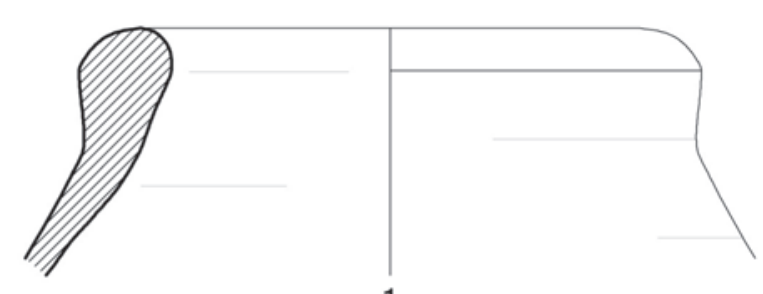

1

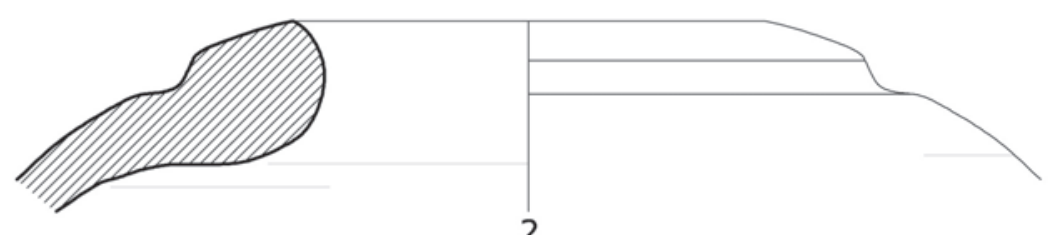

2

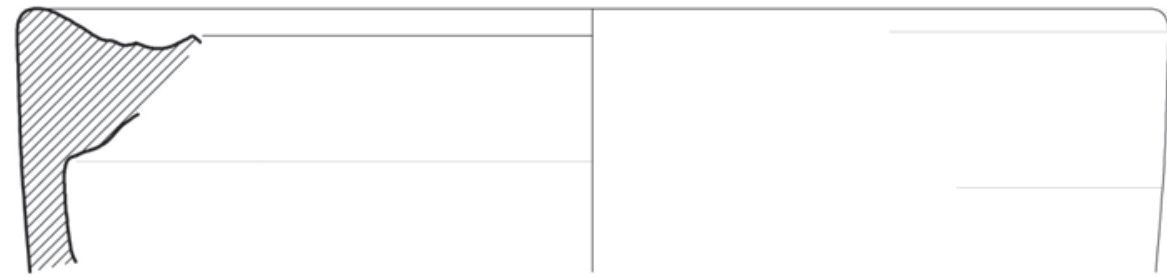

3
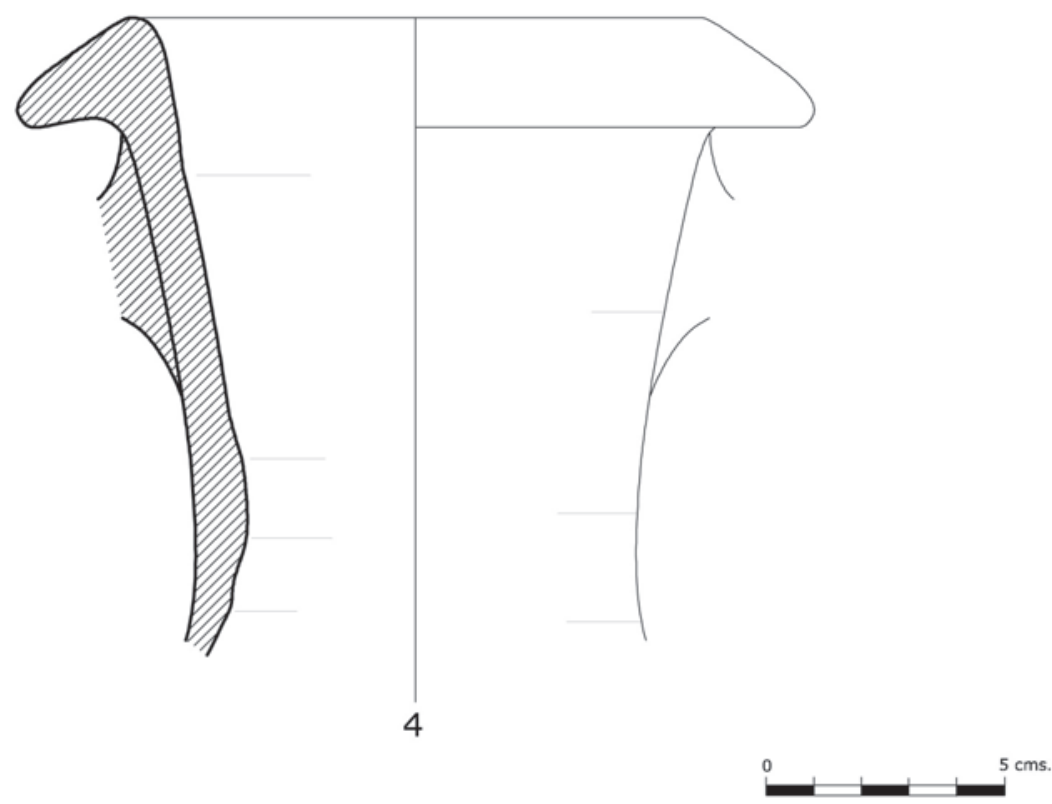

Figura 18. Material cerámico procedente de los estratos de amortización (UUEE 11076, 11077 y 11086) que amortizaban los ambientes n. ${ }^{\circ} 1$ y 2 de la muralla púnica (dib. S. Pérez-Cuadrado Martínez).

En el nivel de incendio documentado en el interior del ambiente n. ${ }^{\circ} 1$ (UE 11088), sólo se ha recuperado parte del borde y cuello de un ánfora greco-itálica (fig. 18.4) provista de un borde exvasado con labio inclinado de base cóncava, que podría incluirse en el grupo de bordes bd4 diferenciado en Lattes, fechado genéricamente entre 225 y 100 a.C. (Py - Adroher Sánchez, 2001:62).
En este conjunto de producciones cerámicas y sus formas más significativas destaca la presencia mayoritaria de producciones importadas fabricadas en regiones bajo control púnico, como es el caso de la zona del Estrecho de Gibraltar, la isla de Ibiza, el área norteafricana y, posiblemente, el Mediterráneo central. Estas producciones están bien constatadas en los niveles de época bárquida de Qart Hadast, contrastando con la escasa repre- 
sentatividad de las producciones ibéricas locales. En concreto, la composición de la vajilla fina de mesa refleja una situación muy similar a la del resto de niveles púnicos de la ciudad, donde predominan las Campanienses A y las producciones ebusitanas (Ruiz, 2004:92-93). Así pues, la formación de estos niveles debe situarse a finales del siglo III o en los primeros años del II a.C., lo que acredita para las estructuras por ellos amortizados una cronología, en todo caso, inmediatamente anterior, muy posiblemente consignable en las últimas décadas de dicha centuria.

\section{INTERPRETACIÓN DE LA EVIDENCIA ARQUEOLÓGICA: LA HIPÓTESIS DE LA MURALLA PÚNICA}

Con los datos expuestos en los capítulos precedentes, ¿cuál es la interpretación y funcionalidad atribuible a esta construcción de carácter longitudinal? En su espléndida descripción de la topografía de la plaza púnico-romana, Polibio refiere que $[. .$.$] por las partes restantes está rode-$ ada de colinas, dos altas y escabrosas y otras tres mucho más bajas, aunque están llenas de cavernas y malos pasos. De éstas la mayor está al oriente, se extiende hasta el mar, y sobre ella se ve el templo de Esculapio. Hacia el occidente le corresponde otra de igual situación sobre la cual está fundado un suntuoso palacio, obra, según dicen, de Hasdrúbal, cuando afectaba la monarquía. [...] (X, 10, 1), es decir, cuando se desarroló la ocupación militar de la península Ibérica tratando de implantar una suerte de protectorado o prefectura militar. Esta referencia prueba dónde estaba la arx o ciudadela de la ciudad púnica y que en ella había construido un suntuoso palacio, obra del general cartaginés. Por tanto, una primera hipótesis a considerar sería que la estructura ahora documentada correspondiese a alguna de las construcciones, todas desconocidas, pertenecientes de la residencia del caudillo.

Sin embargo, el largo trazado y la posición topográfica de esta estructura arquitectónica son elementos que, sumados a su conformación tipológica, permiten sustentar una segunda hipótesis de interpretación más razonable. En efecto, estamos ante una estructura construida mediante la técnica del doble paramento paralelo y con compartimentos interiores ejecutados con muros perpendiculares dispuestos a intervalos más o menos regulares. De marcado desarrollo longitudinal, tiene unos $36 \mathrm{~m}$ de envergadura máxima docu- mentada y una anchura de algo más de $6 \mathrm{~m}$, si aceptamos como válidos los datos aportados por las improntas de los cierres septentrional de la cisterna $\mathrm{n}^{\circ} 1$ y meridional del muro sur del hipotético ambiente $\mathrm{n} .{ }^{\circ} 10$. Parece responder, asimismo, a un proyecto bien definido, ejecutado de forma unitaria, y dotado de un marcado sesgo funcional, como denotan su técnica constructiva y la carencia de cualquier indicio asignable a un programa decorativo, que a tenor de la descripción polibiana sí debería estar presente en el referido palacio. Constructivamente, está ejecutada con muros dotados de zócalos de mampostería y alzados de tapial o, más probable, de adobes, posiblemente enlucidos con una fina lechada de cal; también los suelos son simples capas de barro apisonado, colocadas directamente sobre la roca natural recortada y regularizada. Las cubiertas estarían realizadas con tejados planos de mortero hidráulico. Además, se alza, como ya se ha indicado, en el punto más elevado de la vertiente norte de la ciudadela, parcialmente encajada en la roca madre y enfrentada a la laguna o almarjal que protegía la ciudad por el norte.

Estos datos objetivos permiten hipotetizar que estamos ante los restos de una muralla de casernas o casamatas, organizada en dos niveles o terrazas, construida tras la fundación de la ciudad púnica por los Barca. El lienzo defensivo, que estaría enfrentado a la laguna y coronando la escarpada ladera norte del cerro en su punto más elevado -constituyendo una barrera imponente y prácticamente infranqueable-, fue destruido y amortizado, a partir de la cronología de los contextos cerámicos asociados, en los últimos años del siglo III o los iniciales del II a.C. La alternancia en la construcción de zócalos de mampostería y alzados con fábrica de adobes es usual en muchas murallas fenicias y cartaginesas (López Castro Manzano - Alemán, 2010:33). En todo caso, el frente septentrional abierto al estero ha desaparecido por completo, no siendo descartable el empleo en esta zona de un muro de sillares, semejante al constatado en el tramo de muralla de $\mathrm{La}$ Milagrosa. Sin embargo, contradecirían esta posibilidad los restos de mampostería asociada al recorte que delimita por el norte la cisterna $n .^{\circ} 2$. Y, además, este tipo de refuerzo era preciso sobre todo en terrenos llanos, donde la defensa debía ser reforzada al estar expuesta a ataques con arietes $\mathrm{u}$ otras máquinas de guerra semejantes, lo cual no parece necesario en el caso de la escarpada posición que ocupa la cortina defensiva del Molinete. 
Dado el pésimo estado de conservación de sus estructuras es muy difícil analizar la metrología de la obra, aunque la anchura calculada de unos 6,30 m podría evidenciar el recurso a un codo fenicio-púnico de 0,52 m. La distribución interna de la muralla está basada en dos planos aterrazados, habiéndose recuperado, por el momento, los datos más fiables y significativos en la terraza inferior norte. Aunque apenas se conserva una impronta muy parcial del muro septentrional en el límite norte de la cisterna ${ }^{\circ} .^{1}$, podemos suponer la existencia de dos muros paralelos, el más meridional de los cuáles -que vertebra la construcción entera- secciona, se apoya y adapta a la roca natural; de este muro se conserva, en parte, el zócalo de mampostería sobre el que, a tenor de los datos estratigráficos y constructivos procedentes de los estratos de derrumbe de la estructura, se construirían los alzados de tapial o, más probablemente, de adobe. Este sistema basado en la construcción de un muro de aterrazamiento interior contribuiría a la consecución, con un escaso esfuerzo constructivo, de una suerte de substrucción de grandes dimensiones. Asociado a este paramento se ha constatado una serie de tirantes o tabiques interiores, de gran consistencia, perfectamente trabados con él y realizados con la misma técnica constructiva, que generan diversos espacios interiores de planta rectangular o ligeramente trapezoidal, orientadas de norte a sur y dispuestas en batería, siguiendo el sentido longitudinal de la construcción. Dichos tirantes parecen emplazarse a intervalos irregulares, lo que determina que las dimensiones de los compartimentos no sea regular. Estas casernas alternan con cisternas o depósitos para la recogida y almacenamiento de agua, de los que sólo se conservan dos. Trabados con el muro de aterrazamiento principal se constatan los restos de otros paramentos, también orientados de norte a sur, asentados sobre la roca de la cima de la colina y pertenecientes a la terraza superior meridional de la estructura. A pesar de la parcialidad de su estado de conservación y de la ausencia de estratigrafías asociadas, deben pertenecer a la misma estructura, generando pequeños ambientes, algunos de los cuales pudieron servir como pasillos o cajas de escalera, resolviendo de esta manera el acceso a las estancias de la terraza inferior septentrional.

Tipológicamente, este lienzo defensivo se adscribe al género de las murallas de doble paramento y compartimentos interiores, característico de la arquitectura militar fenicio-púnica, comúnmen- te denominado de cajones -cuando éstos estaban rellenos de arcilla, tierra prensada o escombros- o de casernas o casamatas -cuando los espacios se empleaban para el avituallamiento o el hábitat de la tropa- (López Castro - Manzano - Alemán, 2010:41). Estas fortificaciones, que tienen su origen en el levante mediterráneo, en Fenicia y SiriaPalestina, donde se desarrollaron durante los siglos X y IX a.C. como consecuencia de la invención asiria del ariete como máquina de asedio (Wright, 1985:173-174, fig. 86; Pastor, 2008: 11ss.; Montanero, 2008:98-99), fueron las más utilizadas por los fenicios occidentales (Prados Blánquez, 2007:57-80), estando constatadas desde el siglo VIII a.C. en la península Ibérica (Montanero, 2008:91-114); destacan las de Castillo de Doña Blanca (Puerto de Santa María, Cádiz), de mediados del siglo VIII a.C. (Ruiz Mata - Pérez, 1995: 99ss.; Ruiz Mata, 2001:264), y Cabezo del Estaño (Guardamar del Segura, Alicante), de finales de dicha centuria o inicios de la siguiente (González Prats - García, 2000:1528 ss.). La transformación de algunos asentamientos coloniales en entidades urbanas desde finales del siglo VII a.C. en adelante conllevó una nueva fase de desarrollo del modelo de murallas con compartimentos interiores, pudiendo referirse las de Malaka, de comienzos del siglo VI a.C. (Arancibia - Escalante, 2006:62ss.), la nueva del Castillo de Doña Blanca levantada en pleno siglo V a.C., la de Abbera (Cerro de Montecristo, Adra, Almería), de finales del siglo VII o inicios del VI a.C. (López Castro, 2009; López Castro Manzano - Alemán, 2010:42), y la del asentamiento fortificado de Altos de Leveque, próximo al litoral occidental almeriense y emplazado en un punto estratégico de control de los recursos mineros y agrícolas de Abdera, fechada entre la segunda mitad del siglo VI y finales del V-inicios del IV a.C. (López Castro, 2009; López Castro Manzano - Alemán, 2010:27-46, en particular 3035 y 41-42, figs. 3-9). Por último, en el contexto de la nueva arquitectura poliorcética compleja desarrollada por los cartagineses desde finales del siglo V a.C. en el Mediterráneo central y adaptada al uso de poderosas máquinas de guerra, bien constatada en las zonas de dominio púnico en el Mediterráneo central -en particular Túnez, Sicilia y Cerdeña- y, por supuesto, en el mediodía y sureste de Iberia (Bendala - Blánquez, 20022003:145-160; Prados - Blánquez, 2007:57-80), en los siglos IV-III a.C. se desarrollaron sistemas amurallados con compartimentos interiores en 
diversos enclaves peninsulares, destacando el de la ciudad púnica de Carteia (San Roque, Cádiz), donde a finales del siglo IV a.C. uno de los accesos fue fortificado mediante un tramo de muralla de casamatas; en el siglo III a.C. se remodeló la muralla, aprovechando sus estructuras y erigiendo una nueva de casamatas, cuya estructura arquitectónica con zócalos de mampostería y alzados de adobe es muy semejante a la constatadas ahora en el cerro del Molinete de Cartagena. No obstante, en aquella destaca el empleo de mampuestos bien trabajados y calzados con ripios, lo que aporta un plus de regularidad a la obra (Bendala - Roldán Blánquez, 2002:164-165; Roldán - Bendala Blánquez - Martínez, 2006:302; Bendala, 2010:442 ss.). Al margen del debate en torno a la interpretación de parte de la Puerta de Sevilla de Carmona (Sevilla), la antigua Carmo, como perteneciente a una torre púnica o a la platea de cimentación de un templo posterior (Bendala, 1990:27-29, fig. 1a, lám. 3a-b y f; Belén Escacena - Anglada, 1993:219-242; Schattner, 2005:67-98), otra nueva muralla de casamatas, de cremallera y perfectamente adaptada a la topografía del terreno, fue erigida en el siglo III a.C. en el Castillo de Doña Blanca, estando basado su ritmo en la alternancia de cortinas de murallas con casernas y torres cuadrangulares de 10 m de lado (Barrionuevo - Ruiz - Pérez, 1999:117 ss.). Estas últimas, junto a las del siglo III a.C. de Carteia y las de Qart Hadast, se construyeron siguiendo tradiciones helenísticas y responden a planteamientos tácticos y poliorcéticos ligados a la política imperialista de los Barca en Iberia a finales del siglo III a.C.

Con todo, sin duda el mejor parangón para el nuevo lienzo defensivo del Molinete lo aporta el tramo de muralla púnica identificada en la propia Cartagena, en el área del antiguo istmo, concretamente en la vaguada existente entre los cerros de Despeñaperros y San José7. Descubierto en el solar del antiguo colegio de La Milagrosa, junto a la plaza Almirante Bastarreche, consiste en una muralla de casamatas, para cuya ejecución se acometieron explanaciones y recortes de roca previos, integrada por sendos paramentos, el frontal de los cuáles se construyó en opus quadratum de arenisca de tradición helenística, distanciados

7 Sobre el tramo de muralla hallado en el solar de La Milagrosa: Martín - Roldán, 1992:116 ss.; Martín Belmonte, 1993:161-171; Martín, 1994:317-318; Marín, unos $6 \mathrm{~m}$ y unidos por correas de opus africanum que delimitan espacios internos usados como almacenes o como alojamiento de la tropa; tanto el lienzo interior, como los muros transversales tenían alzados de adobe. Por Polibio sabemos que, en esta zona frente al istmo, las murallas estaban dotadas de almenas y eran altas (X, 13), superando posiblemente varios metros de altura.

Los tramos de muralla con casamatas de La Milagrosa y del Molinete son semejantes desde la óptica tipológica, siendo tributarios de un mismo proyecto defensivo-arquitectónico, a pesar de sus diferencias en el plano de las técnicas edilicias empleadas. Ambos evidencian la introducción en la región del sureste, lógicamente a inicios del último tercio del siglo III a.C. (y en todo caso tras la organización de la ciudad en 229/228 a.C.), de una arquitectura poliorcética de tradición feniciopúnica. De hecho, mientras que la anchura entre los lienzos exterior e interior en el paño defensivo del istmo es de algo menos de $6 \mathrm{~m}$ (Martín Roldán, 1992:116), el del Molinete -si aceptamos como válidos los datos proporcionados por la impronta del cierre norte de la cisterna $n .^{\circ} 1$ y por el muro sur del hipotético ambiente $n .^{\circ} 10-$ tendría una anchura de $c a \cdot 6,30 \mathrm{~m}$, magnitud que incluiría las estancias situadas en la terraza superior septentrional. La principal diferencia apreciable entre ambas cortinas radica en que los muros exterior e interior de la del istmo están construidos mediante quadratum y africanum, mientras que en el Molinete tiene todos sus paramentos construidos con zócalos de mampostería trabada con barro y alzados de adobe o tapial, algo que no es excepcional, pues también se constata en las murallas del Castillo de Doña Blanca, construidas en un breve lapso de tiempo y donde dicha técnica se ha interpretado en función de la rapidez de su construcción, el empleo de distintos maestros de obra y la reutilización de material previo (Barrionuevo - Ruiz - Pérez, 1999:119).

Aunque era una plaza fuerte ubicada en la retaguardia de los dominios cartagineses en la península, la defensa y fortificación de Qart Hdâst debió ser objetivo prioritario en razón, no sólo del contexto prebélico en que había acaecido su fundación, si no también de la necesidad de exteriorizar su prestigio como capital de los dominios 
ibéricos de los Barca. Sin embargo, dadas las excelentes defensas naturales del terreno donde se alzó, es muy posible que buena parte de los esfuerzos se centraran en proteger su punto más vulnerable, a saber, el istmo que lo unía a tierra firme, con una sólida muralla con un frente de sillares capaz de repeler un ataque con arietes o máquinas de guerra semejantes. En tanto que para la defensa en la zona alta de la ciudadela -el cerro del Molinete- pudo recurrirse a una obra de factura y ejecución más tosca desde el punto de vista constructivo con el recurso a mampostería y adobes, levantada en todo caso en un lapso reducido de tiempo y ejecutada por diversas maestranzas. Con todo, el recurso al adobe no debe tenerse como desdoro de la obra, pues el propio Plinio (nat. XXXV, 169) destaca, al respecto de los muros de tierra construidos por los cartagineses en la península por orden de Haníbal, su consistencia y fortaleza que los hacía más fuertes que el cemento -caemento firmiores-, señalando cómo en su época aún podían verse en algunos lugares de la geografía hispana otrora bajo dominio púnico (Conde, 2003:44-45).

Respecto a la funcionalidad de los compartimentos interiores de la cerca, cuyo formato y superficie irregular está determinada por la adaptación de la obra a la topografía del terreno, Apiano ( $L i b .95)$ reseña que en los espacios internos de las murallas de Cartago estaban los establos, abrevaderos y almacenes para el abastecimiento de la tropa. De igual modo, en Cartagena las casernas pudieron dedicarse al almacenamiento de materiales y suministros para la defensa y mantenimiento de la guarnición militar acuartelada en la ciudadela, incluidos víveres y agua, que quedaría almacenada en los grandes depósitos documentados. Sobre las cubiertas de mortero impermeable de las cisternas discurriría el paso de ronda, que serviría también para la recogida del agua de lluvia, su canalización y filtrado hacia los aljibes. La inclusión de depósitos en los sistemas defensivos, que aseguraba el abastecimiento hídrico en caso de asedio, está constatado en otros ejemplos de arquitectura militar cartaginesa, como por ejemplo las defensas de Ras ed-Drek, en el cabo Bon (Nabeul, Túnez), donde se construyeron dos cuerpos edificados en ángulo provistos de cinco cisternas de gran capacidad (Lancel, 1994:245). En la península Ibérica, en concreto en algunos enclaves ibéricos convertidos en puestos de control púnico de su área de influencia, se conocen destacadas obras de ingeniería militar con cisternas. Sería el caso del Tossal de Manises (Albufereta, Alicante) donde se construyó en la segunda mitad del siglo III a.C. un complejo de torres, poternas y muros avanzados que configuraron un antemural o proteichisma; en las torres VI y VIII se incluyeron varias cisternas a bagnarola, muy similares a las del Molinete, destinadas a almacenar el agua recogida en las cubiertas de las torres (Olcina - Guilabert - Tendero, 2010:236 ss.).

La cortina defensiva del Molinete debía extenderse por el borde superior de la vertiente septentrional del cerro. El hecho de que se proyecte por el este hasta prácticamente $1 \mathrm{~m}$ del santuario púnico-romano de Atargatis, a lo que debe sumarse la inclinación que, en este punto, muestra el único tramo de muro conservado (UE 12217), parece evidenciar que la muralla quebraría en este punto, cambiando su orientación en ángulo recto hacia el norte. Quizás este ángulo del recinto amurallado actuase a modo de torre avanzada, generando un bastión angular que reforzaría la defensa de la zona. Por consiguiente, es posible que -al menos en el flanco septentrional de la cima del cerro- la muralla tuviese un diseño en cremallera -como ocurre con el lienzo del Castillo de Doña Blanca-, caracterizado por un trazado regularmente quebrado y adaptado a la propia orografía natural, lo que proporcionaría nuevos ángulos de tiro para alcanzar a los atacantes más próximos a la muralla. Avala la existencia de este trazado en cremallera el hecho de que la posterior defensa de época romana, que seguía -como más abajo expondremos- el mismo trazado que la púnica en esta zona de la ciudadela, estuviese ampliamente retranqueada al norte, envolviendo algunas casas de época republicana dispuestas a unos $30 \mathrm{~m}$ al este del tramo de muralla púnica conservada.

Llegados a este punto, se suscita un interrogante: ¿el lienzo de muralla hallado en el flanco norte del Molinete debe adscribirse al sistema defensivo general de la ciudad púnica, al que asimismo perteneció el exhumado en el solar de La Milagrosa, o -por el contrario- formó parte de las defensas de la acrópolis ocupada por el palacio de Hasdrúbal, que contaba con una guarnición de 1000 mercenarios en el momento previo al ataque de Escipión (Pol. X, 8, 4) y donde Magón se acantonó con 500 de ellos en el transcurso del asedio (Pol. X, 12, 2-3)? Polibio indica que las aguas del estero que delimitaba por el norte la ciudad se 
abatían sobre las fortificaciones. También Apiano advierte que en la zona de la laguna el muro era bajo y [aquélla] lo bañaba con sus aguas (App. $I b .21$ ). Podría pensarse, entonces, que el tramo de muralla ahora documentado, que se alza en la cota más elevada del flanco norte del cerro y, por consiguiente, a más de $30 \mathrm{~m}$ de altitud sobre el nivel del mar y de las aguas de la laguna interior, perteneciese al sistema defensivo de la ciudadela antes que al de la ciudad; y dada su posición en la cumbre del cerro, no precisaría de una altura demasiado elevada, siendo ya de por sí inaccesible dado lo escarpado de la ladera que lo precedía.

Sin embargo, el hecho de que la cortina defensiva estuviese en este punto a una distancia considerable de la laguna no debe entenderse, a nuestro juicio, como contradictorio respecto a las noticias transmitidas por Polibio y Apiano. Cuando éstos señalan que las aguas bañaban la muralla debían estar refiriéndose posiblemente a la zona septentrional de la actual calle Serreta, allá por donde el reflujo del agua de la laguna hizo emerger un trecho de tierra firme adyacente a la muralla y por donde precisamente se produjo el asalto y posterior toma de la ciudad. Con estos bastiones reforzados por el agua, cabía prever -como acertadamente hicieron los romanos- que en caso de ataque las murallas tendrían por ese lado menor número de defensores y serían más vulnerables (Lancel, 1997:179). A este episodio de la conquista pueden vincularse los niveles de destrucción que amortizan un conjunto de instalaciones púnicas de carácter industrial constatadas en los solares 8 y 12 de dicha calle, asociadas con actividades pesqueras y quizá pertenecientes a un barrio marinero ubicado en la ladera baja suroccidental del Monte Sacro, en un punto muy próximo al linde con la antigua laguna ${ }^{8}$. Por tanto, la muralla del Molinete pudo pertenecer al sistema defensivo de la ciudad; adaptándose a la topografía del cerro y a sus declives occidental y oriental, se dirigiría de forma quebrada hacia el noreste para alcanzar la colina que llevaba el nombre de Cronos (Pol. X, 10, 10), identificada con el actual Monte Sacro, protegiendo así pues la vaguada existente entre esta elevación y la ciudadela.

Pero también la acrópolis estaba fortificada. Sabemos que cuando aconteció el famoso episo-

8 Martín Camino - Roldán Bernal, 1997:89. Al mismo episodio deben asociarse los niveles constatados sobre el pavimento de una calzada hallada en la calle que delimitaba la vertiente sur del cerro de la Concepción (Izquierdo dio de la laguna, 500 hombres de Escipión -tras vadearla sin dificultad- se acercaron a la base de la muralla y comenzaron a escalarla sin que pudieran hacer nada para evitarlo los defensores cartagineses (concentrados en intentar repeler el ataque por el acceso principal); entonces las tropas romanas entraron en la ciudad, se dirigieron a la puerta y abrieron sus batientes para que el resto del contingente accediese, refugiándose Magón con unos pocos hombres en la acrópolis (Fernández, 2005:63). La ciudadela debía estar, lógicamente, protegida por su propia línea defensiva, siendo posible que la muralla del Molinete, además de ser parte de las defensas de la plaza, también lo fuese de la acrópolis. El caso de la ciudadela de Qart Hadast no sería un unicum, habiendo sido defendido también el perímetro de la acrópolis de Baria (Villaricos) mediante la excavación de un foso en un momento ya tardío del siglo III a.C., quizás en conexión con el avance de P. Cornelio Escipión tras la toma de Cartagena en 209/208 a.C. para controlar las bases navales púnicas. Desde esta línea defensiva en la zona norte de la ciudad/acrópolis podría considerarse, como creyeron Beltrán y otros autores, que la guarnición apostada en la ciudadela no se percató de la presencia de un reducido grupo de hombres que avanzase pegado a la base del lienzo inferior por efecto del reflujo9 ${ }^{9}$, lo que pudo suceder, como hemos referido, en el entorno de la zona norte de la actual calle Serreta. Por consiguiente, es muy probable que esta cortina formase parte, a la par, del sistema defensivo de la ciudad y de la propia arx o ciudadela.

La muralla púnica sufrió un incendio y posterior colapso que, en base a criterios estratigráficos y cerámicos, pueden fecharse en un momento indeterminado de finales del siglo III o comienzos del II a.C. Tras la amortización de la muralla y sobre sus restos fue levantada, en un momento cronológicamente asimismo impreciso del II a.C., una segunda muralla, ya de filiación romana, compuesta igualmente por un doble paramento con compartimentos interiores, sustentada en zócalos de mampostería y con alzados seguramente de adobe. Esta evidencia arqueológica tiene dos posibilidades de interpretación. La pri-

\footnotetext{
- Zapata, 2005:281).
}

9 Beltrán, 1947:141; Cordente, 1992:427; Cabrero, 2000:8182; Fernández, 2005:65 
mera, que la muralla púnica hubiese sido destruida en el invierno de 209-208 a.C. en el contexto de la conquista romana de la ciudad y su acrópolis, y que pronto hubiese sido sustituida por una nueva defensa romana que seguiría la misma orientación este-oeste que su precedente, si bien levemente retranqueada hacia el suroeste en su flanco occidental. De hecho, sabemos que los romanos pusieron especial énfasis en fortificar nuevamente la ciudad, indicándonos, entre otros, Apiano que, tras la toma de la plaza, Escipión dio instrucciones para que se elevara la muralla que daba al lugar de la marea (App. Ib. VI, 24). La orden no es de extrañar, pues la ciudad tenía un altísimo valor simbólico y estratégico y, además, sabemos por Livio que los cartagineses, al mando de Magón, intentaron reconquistarla en el año 206 a.C. (Liv. XXVIII, 36, 4-13; Scullard, 1970:66; Liddell, 1974:54; Cabrero, 2000:87).

Sin embargo, una segunda posibilidad es que la muralla en lo alto del cerro del Molinete hubiese continuado en pie al menos hasta un momento impreciso de mediados del siglo II a.C., al igual que aconteció con el tramo de $\mathrm{La}$ Milagrosa que fue definitivamente amortizado de forma intencionada en esta época (Martín, 1994, 317-318; Ramallo, 2003, 331-338), habiendo sido sustituida por una nueva. Sabemos que tras la toma de la ciudad, la posterior masacre de sus ciudadanos no cesó hasta que las tropas acantonadas en la acrópolis no se rindieron (Pol. X, 15, 4-8; Liv. XXVI, 46, 6-10; Gracia Alonso, 2003, 142), pero desconocemos si hubo lucha en esta zona y en qué grado pudo verse afectada la muralla, aunque la existencia de niveles con carbones y cenizas evidencian un incendio. Es posible que, tras este episodio, las murallas permanecieran en esta zona en ruinas o semiruinas durante algunos años. La orden de Escipión relativa a la reconstrucción podría referirse a los tramos bajos emplazados junto a la laguna, allí por donde se había producido el asalto romano. Esta segunda opción, que llevaría a fechar la muralla romana a mediados del siglo II a.C., encajaría mejor con los materiales cerámicos recogidos en los contextos de destrucción y amortización de la cerca púnica. Además, esta interpretación encontraría su correspondencia en la construcción en esta misma época de otro grueso paramento defensivo cuyos restos se conservan en el cerro de la Concepción, junto al muro de cierre del teatro augusteo, el cual se mantuvo en uso durante prácticamente una cen- turia, periodo tras el cual fue sometido a una profunda reforma que se prolongó en el devenir de la segunda mitad del siglo I a.C. (Ramallo, 2003:339-340).

Sea de una época o de otra, con la construcción en esta zona del cerro de una muralla romana que sustituía a la anterior púnica se conseguía el doble objetivo de proteger la ciudad por su flanco septentrional y amurallar nuevamente la acrópolis. En cierto modo estamos ante un caso semejante al de Carteia, donde la muralla cartaginesa fue seccionada y desmontada de forma intencionada en la segunda mitad del siglo II a.C., en el contexto de una profunda remodelación urbanística y arquitectónica, al objeto de construir sobre ella un segundo lienzo defensivo.

Esta reconstrucción de las murallas de la acrópolis pudo tener un sesgo marcadamente político, además de defensivo, cuya lectura debe interpretarse en clave simbólica. Y, además, podría haberse asociado durante la República tardía a un amplio programa de reocupación del área del palacio de Hasdrúbal y sus construcciones anexas, parte del cual pudo ser sustituido por nuevas instalaciones que simbolizaran la importancia y estatuto de la ciudad. El proceso se aprecia de modo significativo en el área del santuario púnico dedicado a Atargatis, la Dea Syria, que posiblemente formaba parte de la regia púnica y que fue reutilizado a finales del siglo II o inicios del I a.C., añadiéndosele en uno de sus espacios un pavimento de mortero con una cartela epigráfica alusiva a la diosa (Ramallo - Ruiz, 1994, 79-102; Abascal - Ramallo, 1997, 443-444, n. ${ }^{\circ}$ 205; Díaz Ariño, 2008a, 109-110, C17). En un momento impreciso de finales del siglo II a.C. este santuario fue amortizado en parte por la construcción de una nueva área sagrada presidida por un templo itálico, posiblemente peripteros sine postico, de orden toscano, tetrástilo y alzado sobre un elevado podio, al cual se accedía por una escalera monumental desde las terrazas inferiores de la ladera suroriental del cerro. El nuevo templo romano, a cuya construcción se asoció un proceso de urbanización de la vertiente sureste de la cima del cerro con grandes aterrazamientos inspirados en cánones escenográficos de tradición helenística, estaba enclavado en un punto excepcional: el ocupado otrora por un santuario del conjunto palatino de Hasdrúbal, desde el cual se dominaba perfectamente la totalidad de la vaguada interior donde se alzaba la ciudad. Se trataba 
de un enclave privilegiado donde alzar el templo consagrado, posiblemente, a la divinidad poliádica, del cual no transmite noticias Polibio precisamente por ser posterior a su visita. El paralelismo con Carteia y su lectura en clave política es nuevamente evidente; aquí, el foro de la ciudad romana se alzo en el corazón de la antigua colonia púnica, cuya área cultual fue arrasada en parte por la construcción del nuevo templo. En la Nueva Cartago, el santuario y las instalaciones del antiguo conjunto palaciego mandado erigir por Hasdrúbal para gobernar los dominios bárquidas de Iberia, bien pudieron ser a partir de entonces el escenario donde los gobernadores provinciales presidieran tribunales e impartieran justicia en la ciudad eventualmente, pues el sistema de administración de la Hispania citerior conocido en tiempos de Augusto (Strabon, 3, 4, 20) -con una alternancia invernal entre Tarraco y Cartago Nova- puede retrotraerse muy posiblemente al periodo tardorrepublicano (Gimeno, 1994:39-79; Abascal, 2011:290).

\section{Bibliografía}

ABASCAL PALAZÓN, J. M. (2004): "Cultos orientales en Carthago Nova". AA.VV., Scombraria. La historia oculta bajo el mar. Catálogo de la exposición. Murcia, 102-106.

ABASCAL PALAZÓN, J. M. (2009): "El cerro del Molinete y los cultos orientales en Carthago Nova". Noguera Celdrán, J. M. - Madrid Balanza, M. ${ }^{a}$ J. (Edd.), Arx Hasdrubalis. La ciudad reencontrada. Arqueología en el cerro del Molinete / Cartagena. Murcia, 118-119.

ABASCAL PALAZÓN, J. M. (2011): "La administración itinerante en la Hispania Citerior. El funcionario y su familia”. Iglesias Gil, J. M. - Ruiz Gutiérrez, A (Edd.), Viajes y cambios de residencia en el mundo romano. Santander, 288-317.

ABASCAL PALAZÓN, J. M. - RAMALLO ASENSIO, S. F. (1997): La ciudad romana de Carthago Nova: la documentación epigráfica (La ciudad romana de Carthago Nova: fuentes y materiales para su estudio, 3). Murcia.

ARANCIBIA ROMÁN, A. - ESCALANTE AGUILAR, M. M. (2006): "Génesis y consolidación de la ciudad de Malaka". Memoria arqueológica del Museo Picasso. Málaga. Desde los orígenes hasta el siglo V d.C. Málaga, 41-78.

BARRIONUEVO CONTRERAS, F. J. - RUIZ MATA, D. - PÉREZ PÉREZ, C. J. (1999): "Fortificaciones de casernas del Castillo de Doña
Blanca (El Puerto de Santa María, Cádiz)”. XXIV Congreso Nacional de Arqueología (Cartagena, 1997). Murcia, 115-123.

BELÉN DEAMOS, M. - ESCACENA, J. L. ANGLADA, R. (1993): "Arquitectura de tradición fenicia en Carmona (Sevilla)". Spal, 2, 219242.

BELTRÁN MARTÍNEZ, A. (1946): "La conquista de Cartagena por Escipión". Actas y Memorias de la Sociedad Española de Antropología, Etnografía y Prehistoria, XXI, 101-111.

BELTRÁN MARTÍNEZ, A. (1947): "Nueva Interpretación de los textos sobre la conquista de Cartagena por Escisión”. Saitabi, 25-26, 134-143.

BELTRÁN MARTÍNEZ, A. (1948): “Topografía de Carthago Nova". AEspA, XXI, 191-224.

BENDALA GALÁN, M. (1990): "El plan urbanístico de Augusto en Hispania: precedentes y pautas macroterritoriales". Trillmich, W. - Zanker, P. (Edd.), Stadtbild und Ideologie. Die Monumentalisierung hispanische Städte zwischen Republik und Kaiserzeit. München, 25-42.

BENDALA GALÁN, M. (2010): "La retaguardia hispana de Aníbal". Los Púnicos de Iberia: proyectos, revisiones, sintesis (Mainake, 32, 1-2). Málaga, 437-460.

BENDALA GALÁN, M. - BLÁNQUEZ PÉREZ, J. (2002-2003): "Arquitectura militar púnico-helenística en Hispania”. Quesada Sanz, F. - Moret, P. - Bendala Galán, M. (Edd.), Formas e imágenes del poder en los siglos III y II a.d.C.: modelos helenísticos y respuestas indígenas (Seminario Casa de Velázquez-UAM, febrero 2004) (CUPAUAM, 28-29), 145-160.

BENDALA, M. - FERNÁNDEZ OCHOA, C. FUENTES DOMÍNGUEZ, A. - ABAD CASAL, L. (1987): "Aproximación al urbanismo prerromano y a los fenómenos de transición tras la conquista". Los asentamientos ibéricos ante la romanización (Madrid, 1986). Madrid, 121-140.

BENDALA GALÁN, M. - ROLDÁN GÓMEZ, L. BLÁNQUEZ PÉREZ, J. (2002): "Carteia: de ciudad púnica colonia latina”. Jiménez Salvador, J. L. - Ribera i Lacomba, A. (Edd.), Valencia y las primeras ciudades romanas de Hispania. Valencia, 157-172.

CABRERO PIQUERO, J. (2000): Escipión el Africano. La forja de un Imperialismo Universal. Madrid.

CONDE GUERRI, E., (2003): La ciudad de Carthago Nova: La documentación literaria (IniciosJulioclaudios). Murcia. 
CORDENTE VAQUERO, F. (1992): Poliorcética Romana. 218 a.C.-73 p.C.. Madrid.

DE MIQUEL SANTED, L. (1994): “El primer asedio romano de Qart-Hadast (Nueva Documentación Arqueológica)". El mundo púnico. Historia, sociedad y cultura (Cartagena, 1990). Murcia, 5559.

DE SANCTIS, G. (1968²): Storia dei Romani, III.2. Firenze ( $1^{\mathrm{a}}$ edic. Torino, 1916).

EGEA VIVANCOS, A. (2003): "Ingeniería hidráulica en Carthago Nova: las cisternas". Mastia, 2, 109127.

DÍAZ ARIÑO, B. (2008): Epigrafía latina republicana de Hispania (Col-lecció Instrumenta, 26). Barcelona.

FERNÁNDEZ RODRÍGUEZ, D. (2005): “La toma de Carthago Nova por Publio Cornelio Escisión: ¿leyenda o realidad?". Polis. Revista de ideas y formas políticas de la Antigüedad Clásica, 17, 31-72.

GIMÉNEZ TOMÁS, M. - NOGUERA CELDRÁN, J. M. - MADRID BALANZA, M. ${ }^{\mathrm{a}}$ J. - MARTÍNEZ PÉRIS, I. (2011): "Proyecto Parque Arqueológico del Molinete: intervención en la cima". XXII Jornadas de Patrimonio Cultural de la Región de Murcia. Murcia, 95-118.

GIMENO, J. (1994): "Plinio, Nat. hist. III, 3, 21. Reflexiones acerca de la capitalidad de Hispania Citerior". Latomus, 53, 39-79.

GÓMEZ VIZCAINO, A. (2003): "Las murallas de los Austrias en Cartagena (1500-1700). Fuentes documentales y testimonios materiales (cerro del Molinete, calles Adarve y San Antonio el Pobre y Monte Sacro)". Noguera Celdrán, J. M. (Ed.), Arx Asdrubalis. Arqueología e Historia del Cerro del Molinete (Cartagena), vol. I. Murcia, 269-305.

GONZÁLEZ PRATS, A. - GARCÍA MENÁRGUEZ, A. (2000): "El conjunto fenicio de la desembocadura del río Segura (Guardamar del Segura, Alicante)". Barthelemy, M. - Aubet Semmler, M. ${ }^{a}$ E. (Edd.), Actas del IV Congreso internacional de Estudios Fenicios y Púnicos (Cádiz, 1995). Cádiz, vol. 4, 1527-1537.

GRACIA ALONSO, F. (2003): La guerra en la Protohistoria. Héroes, nobles, mercenarios y campesinos. Barcelona.

GUERRERO, V. M. (1996): "Cerámica de cocina en los asentamientos coloniales púnicos de Mallorca”. CuadCastelló, 17, 207-218.

GUERRERO AYUSO, V. M. - ROLDÁN BERNAL, B. (1992): Museo Nacional de Arqueología Marítima (Cartagena). Catálogo de las ánforas prerromanas. Cartagena.
IZQUIERDO, M. P. - ZAPATA PARRA, J. A. (2005): "Restos de calzada romana en la calle Duque $n^{\circ}$ 2 de Cartagena". XVI Jornadas de Patrimonio Histórico. Intervenciones en el patrimonio arquitectónico, arqueológico y etnográfico de la Región de Murcia. Murcia, 281-282.

LANCEL, S. (1994): Cartago. Barcelona.

LANCEL, S. (1997): Aníbal. Barcelona.

LECHUGA GALINDO, M. (1991-93): "La presencia púnica en Cartagena: Testimonios numismáticos". ActaNum, 21-23, p. 155-165.

LIDELL HART, C. H. (1974): Escipión el Africano. Un hombre más grande que Napoleón. Buenos Aires.

LÓPEZ CASTRO, J. L. (2009): "Las ciudades de Abdera y Baria en el sureste de la Península Ibérica". Helas, S. - Marzoli, D. (Edd.), Phönizisches und punisches Städtewesen (Roma, 2007). Mainz, 525-541.

LÓPEZ CASTRO, J. L. - MANZANO AGUGLIARO, F.- ALEMÁN OCHOTORENA, B. (2010): "“Altos de Reveque: un asentamiento fortificado fenicio-púnico en la litoral de Andalucía oriental". AEspA, 83, 27-46.

MADRID BALANZA, M. ' J. (2004): “Primeros avances sobre la evolución urbana del sector oriental de Carthago Nova PERI Ca-4/barrio universitario". Mastia, 3, 31-70.

MARÍN BAÑO, C. (1997-98): “"Un modelo estratigráfico de la Cartagena púnica: la muralla de Quart-Hadast”. AnMurcia, 13-14, 121-140.

MARTÍN CAMINO, M. (1994): “Colonización fenicia y presencia púnica en Murcia". El mundo púnico. Historia, sociedad y cultura. Murcia, 293-324.

MARTÍN CAMINO, M. (1998): “Un contexto cerámico de finales del siglo III a.C.: el vertedero púnico de la Plaza de San Ginés (Cartagena). Les fàcies ceràmiques d'importació a la costa ibèrica, les Balears $i$ les Pitiüses durant el segle III a.C. $i$ la primera meitat del segle II a.C. (Arqueomediterrània, 4). Barcelona, 9-29.

MARTÍN CAMINO, M. - BELMONTE MARÍN, J. A. (1993): "La muralla púnica de Cartagena: valoración arqueológica y análisis epigráfico de sus materiales". AulaOr, 11, 2, 161-171.

MARTÍN CAMINO, M. - ROLDÁN BERNAL, B. (1991-92): "Nota sobre el comercio marítimo en Cartagena durante época púnica a través de algunos hallazgos subacuáticos”. AnMurcia, 7-8, 151-162. 
MARTÍN CAMINO, M. - ROLDÁN BERNAL, B. (1992): “Aspectos arqueológicos y urbanísticos de la Cartagena Púnica”. Historia de Cartagena, IV. Cartagena, 107-149.

MARTÍN CAMINO, M. - ROLDÁN BERNAL, B. (1997a): "Plaza de San Ginés número 1, esquina calle del Duque". Excavaciones arqueológicas en Cartagena. 1982-88 (MemArqMurcia). Murcia, 126-128.

MARTÍN CAMINO, M. - ROLDAN BERNAL, B. (1997b): "Calle Serreta, números 8-10-12". Excavaciones arqueológicas en Cartagena. 198288 (MemArqMurcia). Murcia, 74-94.

MARTÍN CAMINO, M. - ROLDÁN BERNAL, B. (2000): "Cerámica de cocina de importación en la Cartagena púnica: los morteros y grandes platos. Siglo III a.C.". IV Congreso Internacional de Estudios Fenicios y Púnicos, IV (Cádiz, 1995). Cádiz, 1615-1623.

MARTÍNEZ ANDREU, M. (2004): “La topografía en Carthago Nova. Estado de la cuestión”. Mastia, 3, 11-30.

MAS GARCÍA, J. (1979): El Puerto de Cartagena. Cartagena.

MONTANERO, D. (2008): "Los sistemas defensivos de origen fenicio-púnico del sureste peninsular (siglos VIII-III a.C.): nuevas interpretaciones". Costa, B. - Fernández, J. H. (Edd.), Arquitectura defensiva fenicio-púnica. XXII Jornadas de Arqueología Fenicio-Púnica (Eivissa, 2007) (Treballs del Museu Arqueologic d'Eivissa $i$ Formentera, 61). Ibiza, 91-114.

NOGUERA CELDRÁN, J. M. (Ed.) (2003a): Arx Asdrubalis. Arqueología e Historia del Cerro del Molinete (Cartagena), vol I. Murcia.

NOGUERA CELDRÁN， J. M. (2003b): “Arx Asdrubalis. Historia y Arqueología de un espacio privilegiado de Cartagena en la antigüedad". Noguera Celdrán, J. M. (Ed.), Arx Asdrubalis. Arqueología e Historia del Cerro del Molinete (Cartagena), vol. I. Murcia, 13-74.

NOGUERA CELDRÁN, J. M. - MADRID BALAN-

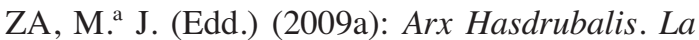
ciudad reencontrada. Arqueología en el cerro del Molinete / Cartagena. Murcia.

OLCINA, M. - GUILABERT, A. - TENDERO, E. (2010): "Lectura púnica del Tossal de Manises (Alicante)". Los Púnicos de Iberia: proyectos, revisiones, sintesis (Mainake, 32, 1-2). Málaga, 229-249.

PASTOR BORGOÑÓN, H. (2008): “Arquitectura defensiva en Fenicia oriental y en el norte de Israel/Palestina". Costa, B. - Fernández, J. H.
(Edd.), Arquitectura defensiva fenicio-púnica. XXII Jornadas de Arqueología Fenicio-Púnica (Eivissa, 2007) (Treballs del Museu Arqueologic d'Eivissa i Formentera, 61). Ibiza, 9-24.

PÉREZ BALLESTER, J. (1998): "El portus de Carthago Nova. Sociedad y comercio tardo-helenísticos". Puertos antiguos y comercio marítimo. III Jornadas de arqueología subacuática (Valencia, 13, 14 y 15 de noviembre de 1997). Valencia, 249-261.

PRADOS MARTINEZ, F. - BLÁNQUEZ PEREZ, J. (2007): "Las fortificaciones coloniales en la Península Ibérica: de los modelos orientales a los sistemas púnico-helenísticos". Berrocal-Rangel, L. - Moret, P. (Edd.), Paisajes fortificados de la Edad del Hierro. Las murallas protohistóricas de la Meseta y la vertiente atlántica en su contexto europeo. Madrid, 57-80.

PY, M. - ADROHER, A. M. - SÁNCHEZ, C. (2001): Corpus des céramiques de l'Age du Fer de Lattes (fouilles 1963-1999). Lattes.

RAMALLO ASENSIO, S. F. (1989): La ciudad romana de Carthago Nova: la documentación arqueológica (La ciudad romana de Carthago Nova: fuentes y materiales para su estudio, 2). Murcia.

RAMALLO ASENSIO, S. F. (2003): “Carthago Nova. Arqueología y epigrafía de la muralla urbana". Defensa y territorio en Hispania de los escipiones a Augusto. Espacios urbanos y rurales, municipales y provinciales. Madrid, 325-362.

RAMALLO ASENSIO, S. F. - RUIZ VALDERAS, E. (1994): "Un edículo republicano dedicado a Atargatis en Carthago Nova". AEspA, 67, 79-102.

RAMALLO ASENSIO, S. F. - RUIZ VALDERAS, E. (2009): "El diseño de una gran ciudad del sureste de Iberia. Qart Hadast". Helas, S. - Marzoli, D. (Edd.), Phönizsyches und punische Städtewesen (Roma, 2007). Mainz, 529-544.

RAMÓN TORRES, J. R. (1994): “El pozo púnico del Hort d'en Xim". Treballs del Museo Arqueologic d'Eivissa e Formentera, 32, 1-83.

RAMÓN TORRES, J. R. (1995): Las ánforas feniciopúnicas del Mediterráneo central y occidental. Barcelona.

RICCI, M. (1974): "Per una cronología delle lucerne tardo-republicane”. RivStLiguri, XXXIX, 2-4, 168-234.

ROLDÁN BERNAL, B. (2003): "El cerro del Molinete de Cartagena: actuaciones arqueológicas recientes". Noguera Celdrán, J. M. (Ed.), Arx Asdrubalis. Arqueología e Historia del Cerro del Molinete (Cartagena), vol. I. Murcia, 75-113. 
ROLDÁN, L. - BENDALA, M. - BLÁNQUEZ, J. MARTÍNEZ, S. (2006): Estudio históricoarqueológico de la ciudad de Carteia (San Roque, Cádiz), 1994-1999. Madrid.

RUIZ DE ARBULO, J. (1992): "Tarraco, Carthago Nova y el problema de la capitalidad en la Hispania Citerior republicana”. Miscel.lània arqueològica a Josep M. Recasens. Tarragona, 115-130.

RUIZ MATA, D. (2001): “Arquitectura y urbanismo de la ciudad protohistórica de Castillo de Doña Blanca (El Puerto de Santa María, Cádiz)". Ruiz Mata, D. - Celestino Pérez, S. (Edd.), Arquitectura oriental y orientalizante en la península Ibérica. Madrid, 261-274.

RUIZ MATA, D. - PÉREZ, C. (1995): El poblado fenicio del Castillo de Doña Blanca (El Puerto de Santa María, Cádiz). Puerto de Santa María.

RUIZ VALDERAS, E. (1999): “Las cerámicas campanienses del siglo III a.C. en Cartagena: el cerro del Molinete". XXIV Congreso Nacional de Arqueología (Cartagena, 1997). Murcia, 33-42.
RUIZ VALDERAS, E. (2004): “Cerámicas campanienses de Cartagena: el registro arqueológico y la dinámica comercial". Lechuga, M. (Coord.), Scombraria. La historia oculta bajo el mar. Catálogo de la exposición. Murcia, 88-100.

RUIZ VALDERAS, E. - MADRID BALANZA, M. ${ }^{\mathrm{a}}$ J. (2002): "Las murallas de Cartagena en la Antigüedad". Estudio y catalogación de las defensas de Cartagena y su bahía. Murcia, 19-84.

SCHATTNER, Th. G. (2005): "La Puerta de Sevilla en Carmona y otras puertas romanas en la Península Ibérica". Rómula, 4, 67-98.

SCHULTEN, A. (1935): Fontes Hispaniae Antiquae, III. Las guerras de 237-154 a. de J.C.. Barcelona.

SCULLARD, H. H. (1970): Scipio Africanus. Soldier and Politician. London.

WALBANK, F. W. (1967): A Historical Commentary on Polybius. Oxford.

WRIGHT, G. H. R. (1985): Ancient building in South Syria and Palestine. Leiden-Köln. 
